\title{
Inorganic Self-Assembly Through Sequential Complexation in the Formation of Bimetallic and Trimetallic Architectures from Multisite Ligands Based on 5,5'-Disubstituted 2,2'-Bipyridines
}

\author{
Vanderlei G. Machado, ${ }^{a, b, \#}$ Antonio S. Mangrich ${ }^{b}$ and Jean-Marie Lehn ${ }^{*, a}$ \\ ${ }^{a} I S I S$, Université Louis Pasteur, 4, rue Blaise Pascal F-67000, Strasbourg, France \\ ${ }^{b}$ Departamento de Química, Universidade Federal do Paraná, UFPR, 81531-970, Curitiba-PR, Brazil
}

\begin{abstract}
Dois pré-ligantes 2,2'-bipiridínicos 5,5'-dissubstituídos apresentando em sua estrutura dois ou três sítios de coordenação [5,5'-bis(ácido $N$-metil-hidroxâmico)-2,2'-bipiridina (4) e 5-metil-5' (ácido $N$-metil-hidroxâmico)-2,2-bipiridina (10)] foram sintetizados. Estes ligantes foram empregados no estudo de uma estratégia de automontagem por complexação seqüencial. De acordo com este conceito, o primeiro metal adicionado organiza os substituintes-ligantes das posições 5,5' para a complexação do segundo íon metálico adicionado seqüencialmente. A adição de $\mathrm{Fe}^{2+}$ a uma solução contendo 4 levou à formação do complexo $\mathrm{Fe}^{2+}$-tris(bipiridil). A adição de $\mathrm{Fe}^{3+}$ a este complexo rendeu uma arquitetura trimetálica. O ligante $\mathbf{1 0}$ levou à formação de uma mistura de arquiteturas bimetálicas pela adição seqüencial de íons $\mathrm{Fe}^{2+}$ e $\mathrm{Fe}^{3+}$. No entanto, quando a ordem de adição foi alterada, somente um complexo bimetálico foi obtido. Isto se deve ao fato de que o primeiro metal adicionado $\left(\mathrm{Fe}^{3+}\right)$ age como um molde, organizando os ligantes bipiridínicos e pré-formando uma cavidade adequada para o íon $\mathrm{Fe}^{2+}$.
\end{abstract}

Two multisite 5,5'-disubstituted 2,2'-bipyridine ligands containing $N$-methyl hydroxamic acids as substituents [5,5'-bis ( $N$-methylhydroxamic)-2,2'-bipyridine (4) and 5-methyl-5' $-(N$ methylhydroxamic)-2,2-bipyridine (10)] were synthesized. These ligands were used in order to illustrate the strategy of self-assembly through sequential complexation. According to this concept, the first metal added organizes the ligands disposed in 5,5'-positions to accomodate the second metal ion that is sequentially added. Thus, addition of $\mathrm{Fe}^{2+}$ to a solution of $\mathbf{4}$ led to a $\mathrm{Fe}^{2+}$-tris(bipyridine) complex. Addition of $\mathrm{Fe}^{3+}$ to this solution yielded a trimetallic architecture, which was characterized. Ligand 10 yielded a mixture of bimetallic architectures through complexation with $\mathrm{Fe}^{2+}$ followed by $\mathrm{Fe}^{3+}$ ions. However, if the order of metal addition is changed, only one bimetallic complex is obtained. This is due to the fact that the first metal ion added $\left(\mathrm{Fe}^{3+}\right)$ acts as a template, organizing the bipyridine ligands and preforming an adequate cavity for the $\mathrm{Fe}^{2+}$ ion.

Keywords: inorganic self-assembly, sequential ligands, sequential complexation, metalloexoreceptors

\section{Introduction}

Self-assembly of inorganic architectures from programmed components has been an extensively investigated field of supramolecular chemistry in recent years. ${ }^{1-6}$ Such processes involve the design of programmed supramolecular species, which are spontaneously formed from carefully constructed ligands and metal ions able to

* email: lehn@isis.u-strasbg.fr

\# Present address: Centro Tecnológico, GRUCENSO, Pró-Reitoria Acadêmica, Universidade do Sul de Santa Catarina, CP 370, 88704900, Tubarão-SC, Brazil read the binding sites according to their coordination algorithm. ${ }^{1,2,6}$ This strategy has allowed the synthesis of a great variety of inorganic architectures, ${ }^{1-6}$ such as double${ }^{7}$ and triple-helical ${ }^{8}$ complexes, rack-, ${ }^{9}$ grid- ${ }^{10}$ and cagetype ${ }^{11}$ arrays of metal ions synthesized by our own group. The design of ligands containing different coordination sites has spontaneously yielded structures having different metal ions at specific locations, as in heterometallic helicates ${ }^{12}$ and in large multicomponent arrays. ${ }^{13}$

Exoreceptors are receptor molecules where the substrate fixation sites are divergent, in opposition to the convergent chemistry of the endoreceptors. ${ }^{1,6,14,15}$ The different kinds of exoreceptors include organic as well as 
inorganic entities. For instance, linear koilands, are rigid and compact exoreceptors with two diametrically opposing cavities, and connector molecules with two extremities complementary to the cavities of the exoreceptor. ${ }^{14}$ In the metallo-exoreceptors, ${ }^{15}$ the ligands bearing the groups responsible for the fixation of the substrate, are assembled by the central metal ion, which has a double function: it disposes the recognition units according to the coordination geometry of the ion, and it also introduces strong electrostatic interactions due to the charge of the ion.

Recently, we have discussed the potential presented by self-assembled metallo-exoreceptors generated by complexation of 5,5'-disubstituted 2,2'-bipyridines (bipys) with a suitable metal ion. ${ }^{6}$ Thus, the octahedral coordination of 5,5'-disubstituted 2,2'-bipyridines by a metal ion such as $\mathrm{Fe}^{2+}$ will enable the substituents to acquire a proper spatial orientation, leading to the formation of a ditopic metallo-exoreceptor presenting two potential substrate binding subunits. These receptors may be of importance in many areas of supramolecular chemistry, such as enzyme modelling, anionic recognition and in the development of molecular devices. Their use depends in principle only on the design of the 2,2'-bipyridine ligand, more specifically on the nature of the substituents in 5,5'positions. If the resultant metallo-exoreceptor possesses potential binding units as substituents, the complexation at these sites with other metal ions or with other substrates occurs in a defined sequence. Thus, transition metal complexes of aminoacid ${ }^{16}$ and amide ${ }^{17}-5,5^{1}$-disubstitutedbipy ligands have been shown to form receptor pockets along the (pseudo)-threefold axis, to which chloride counteranions may bind. Three iron (II) complexes of 5,5'bis(ethoxycarbonylamino)-2,2'-bipyridine have been shown to be able to encapsulate sulfate, perchlorate, or nitrate anions. ${ }^{18}$ This strategy of self-assembly through sequential complexation may involve, in a first step, the synthesis of specially designed sequential ligands ${ }^{16-19}$ capable of presenting hierarchical assembly features.

Hydroxamic acids are hard ligands capable of complexing hard ions such as $\mathrm{Fe}^{3+}$, while the soft bipy ligands bind soft metal ions such as $\mathrm{Fe}^{2+}, \mathrm{Co}^{2+}$ and $\mathrm{Ru}^{2+}$. These features allowed the synthesis of molecular redox switches possessing these two types of ligands anchored on a triple-stranded ligand ${ }^{20}$ or on a calix[4]arene ring. ${ }^{21}$ Chemical oxidation and reduction leads to the reversible translocation of the metal ion between the soft and the hard sites, and these changes can be easily monitored spectroscopically. Here, we report the synthesis and properties of two sequential ligands $\mathbf{4}$ and $\mathbf{1 0}$ that bear either a single, or two, hydroxamic acid groups anchored on a bipy moiety with a view to illustrating the concept of sequential complexation through the formation of bimetallic and trimetallic architectures.

\section{Experimental}

General

All chemicals used were high-purity commercial reagents. Deionized water was used in all measurements. This solvent was boiled and bubbled with nitrogen and kept in a nitrogen atmosphere to avoid the presence of carbon dioxide. THF was distilled from sodium using benzophenone as an indicator. ${ }^{22}$ Dichloromethane was distilled from calcium hydride. ${ }^{22}$ All other solvents employed in the reactions were used as received. Tetrakis(triphenylphosphine)palladium (0), $\left[\mathrm{Pd}\left(\mathrm{PPh}_{3}\right)_{4}\right]$, was prepared according to the procedure described in the literature. ${ }^{23} \mathrm{~N}$-methyl acetohydroxamic acid was prepared by reacting $N$-methylhydroxylamine with acetyl chloride in basic methanol. ${ }^{24}$ The stock $\mathrm{FeCl}_{3}$ solutions were standardized with a standard solution of triply recrystallized $\mathrm{K}_{2} \mathrm{Cr}_{2} \mathrm{O}_{7}$, after reduction with stannous ions, according to normal procedures. ${ }^{25}$

\section{Instrumentation and physical measurements}

Melting points (mp) were obtained on a Kofler hot stage and were uncorrected. TLC was performed on HF-254 (Merck) plates, visualizing with a $254 \mathrm{~nm}$ UV lamp. UV-Vis experiments were made with Cary 13 and HP-8453 spectrophotometers equipped with a thermostated bath and all measurements were performed at $25^{\circ} \mathrm{C}$. The $\mathrm{pH}$-meter titrations were performed with a Metrohm-636 titrimeter. Nuclear magnetic resonance spectra were recorded on Bruker AC 200 (200 MHz) or Bruker AM 400 spectrometers. Chemical shifts were recorded in ppm with the solvent resonance as the internal standard. Data are reported as follows: chemical shift, multiplicity ( $\mathrm{s}=$ singlet, $\mathrm{d}=$ doublet, $\mathrm{t}=$ triplet, $\mathrm{m}=$ multiplet, $\mathrm{dd}=$ doublet of doublet, $\mathrm{bs}=$ broad singlet), integration and coupling constants (Hz). Electronic paramagnetic resonance (EPR) experiments were carried out at $77 \mathrm{~K}$ on a Bruker ESP $300 \mathrm{E}$ spectrometer operating at Xband frequency $(\sim 9.5 \mathrm{GHz})$ with $100 \mathrm{kHz}$ field modulations, modulation amplitude equal to $2.024 \mathrm{G}$ and microwave power approximately equal to $20 \mathrm{~mW}$. The spectra were recorded in first and second derivative mode for the powdered and frozen solution $(77 \mathrm{~K})$ samples in quartz tubes. WINEPR ${ }^{\circledR}$ software was also used to treat the spectra. Infrared spectra were measured on a Bomen FTIR spectrophotometer, with $\mathrm{KBr}$ pellets. Electron impact $\left(\mathrm{EI}^{+}\right)$mass spectra were obtained 
with a Fisons Instruments TRIO 2000 (Manchester) spectrometer. Fast-atom bombardment $\left(\mathrm{FAB}^{+}\right)$mass spectra were recorded on a Micromass AUTOSPEC-M-HF (Manchester) instrument and electron spray $\left(\mathrm{ESI}^{+}\right)$mass spectra were obtained on a VG BIOQ triple quadrupole Quattro II (Micromass, Altrincham) spectrometer. Microanalyses were determined by a Perkin Elmer 2400 elemental analyzer.

Synthesis of the ligands and their metal complexes

Compounds 1, 2, 3 and $\mathbf{5}$ were prepared according to the procedures described in the literature $\left(\mathbf{1},,^{26,27} \mathbf{2},{ }^{28} \mathbf{3}^{29}\right.$ and $\left.\mathbf{5}^{30}\right)$.

\section{5,5'-Bis(N-methylhydroxamic)-2,2'-bipyridine (4)}

A mixture of $N$-methyl hydroxylammonium hydrochloride (14.1 $\mathrm{mL}$ of an aqueous solution $4 \mathrm{~mol} \mathrm{~L}^{-1}$; $56.4 \mathrm{mmol}$ ) with $\mathrm{NaOH}(14.1 \mathrm{~mL}$ of an aqueous solution $3.5 \mathrm{~mol} \mathrm{~L}^{-1}$ ) was added to the 5,5'-bis(chlorocarbonyl)2,2'-bipyridine (2.30 g; $8.20 \mathrm{mmol})$ at room temperature, while stirring. The mixture was then stirred overnight. The suspension was adjusted to $\mathrm{pH} 7$, and the white solid was collected, and washed with water and acetone. The product was dried ( $2.1 \mathrm{~g} ; 85 \%$ yield); ${ }^{1} \mathrm{H}$ NMR (200 MHz, DMSO$\left.\mathrm{d}_{6}\right): \delta 3.31(6 \mathrm{H}, \mathrm{s}), 8.18(2 \mathrm{H}, \mathrm{dd}, J 2.1$ and $8.2 \mathrm{~Hz}), 8.46(2 \mathrm{H}$, d, J $8.3 \mathrm{~Hz}), 8.93(2 \mathrm{H}, \mathrm{d}, J 2.1 \mathrm{~Hz}), 10.31(2 \mathrm{H}, \mathrm{s})$; IR (KBr) $v_{\max } / \mathrm{cm}^{-1}: 3553,3490,3145,2822,1734,1655,1600$, 1500, 1423, 1385, 1221, 1174, 1082, 1024, 951, 910, 849, 753, 644; MS (FAB ${ }^{+}$): 303.1 (100); Anal. calcd. for $\mathrm{C}_{14} \mathrm{H}_{14} \mathrm{~N}_{4} \mathrm{O}_{4}: \mathrm{C}, 55.63 ; \mathrm{H}, 4.64 ; \mathrm{N}, 18.54$. Found: $\mathrm{C}, 55.85$; H, 4.60; N, 18.80 .

\section{5-Methyl-2-trimethyltinpyridine (6)}

To a closed flask, protected from moisture by argon flow, $n$-butyl lithium $1.6 \mathrm{~mol} \mathrm{~L}^{-1}$ solution in hexane $(35.8$ $\mathrm{mL}, 57.2 \mathrm{mmol}$ ) was added. The temperature in the flask was lowered to $-78{ }^{\circ} \mathrm{C}$. 2-Bromo-5-methylpyridine (9.36 g, $54.4 \mathrm{mmol}$ ) was added drop by drop as a dried THF solution, while stirring. The color of the solution changed to dark brown. Trimethyltinchloride $1 \mathrm{~mol} \mathrm{~L}^{-1}$ solution in THF (54.4 mL, $54.4 \mathrm{mmol}$ ) was added drop by drop while stirring. At the end of the addition, the color of the solution changed to yellow. The reaction mixture was filtered and the solvent was rotary-evaporated. The oily pale yellow product obtained was distilled under vacuum and the first fraction was collected $\left(75^{\circ} \mathrm{C}, 3.5 \mathrm{~mm} \mathrm{Hg}\right)(11.34 \mathrm{~g}, 81.5 \%)$. This product is unstable and must be used immediately in the next reaction. ${ }^{1} \mathrm{H} \mathrm{NMR}\left(200 \mathrm{MHz}, \mathrm{CDCl}_{3}\right): \delta 2.29(3 \mathrm{H}$, s, $\left.\mathrm{CH}_{3}\right), 7.32(1 \mathrm{H}, \mathrm{d}, J 7.8 \mathrm{~Hz}), 7.36(1 \mathrm{H}, \mathrm{d}, J 8.6 \mathrm{~Hz}), 8.59$ (1 H, s).

5-Carboxyethyl-5'-methyl-2,2'-bipyridine (7)

A solution of 2-chloro-5-ethylnicotinate $(4.0 \mathrm{~g}, 21.6$ mmol), 5-methyl-2-trimethyltinpyridine (5.79 g, 22.6 $\mathrm{mmol})$ and $\left[\mathrm{Pd}\left(\mathrm{PPh}_{3}\right)_{4}\right](2.9 \mathrm{~g}, 2.51 \mathrm{mmol})$ in dry toluene (96 mL) was refluxed for $72 \mathrm{~h}$. The solvent was removed and dichloromethane was added to the black oil. The black solid separated was filtered off and the liquid, after removal of the solvent, was chromatographied $\left(\mathrm{Al}_{2} \mathrm{O}_{3}\right.$ II-III activity, dichloromethane as eluent). The fractions were collected and the solvent was rotary-evaporated. The yield obtained was $4.09 \mathrm{~g}(78 \%)$ of a pale yellow solid. ${ }^{1} \mathrm{H}$ NMR (200 $\left.\mathrm{MHz} \mathrm{CDCl}_{3}\right): \delta 1.43(3 \mathrm{H}, \mathrm{t}, J 7.1 \mathrm{~Hz}), 2.42(3 \mathrm{H}, \mathrm{s}), 4.43$ $(2 \mathrm{H}, \mathrm{q}, J 7.1 \mathrm{~Hz}), 7.66(1 \mathrm{H}, \mathrm{dd}, J 1.7$ and $8.0 \mathrm{~Hz}), 8.37(1 \mathrm{H}$, $\mathrm{dd}, J 1.5$ and $8.4 \mathrm{~Hz}), 8.39(1 \mathrm{H}, \mathrm{d}, J 8.3 \mathrm{~Hz}), 8.46(1 \mathrm{H}, \mathrm{d}, J$ $8.0 \mathrm{~Hz}), 8.53(1 \mathrm{H}, \mathrm{d}, J 1.7 \mathrm{~Hz}), 9.25$ (1H, d, J $1.5 \mathrm{~Hz})$; IR $(\mathrm{KBr}) v_{\max } / \mathrm{cm}^{-1}: 3052,2985,1719,1591,1552,1461$, 1387,1367, 1295, 1279, 1238, 1135, 1028, 851, 788, 747; MS (EI'): 197.1 (100), 242.2 (60).

\section{5-Carboxy-5'-methyl-2,2'-bipyridine (8)}

5-Carboxyethyl-5'-methyl -2,2'-bipyridine (1.0 g; $4.13 \mathrm{mmol})$ was taken up in methanol $(5 \mathrm{~mL})$ to which $\mathrm{NaOH} 1 \mathrm{~mol} \mathrm{~L}^{-1}(5 \mathrm{~mL})$ was added and the solution stirred at room temperature for about $5 \mathrm{~h}$. The solvent was evaporated and the residue dissolved in a minimum amount of water. The solution was extracted with dichloromethane $(2 \times 15 \mathrm{~mL})$ and the aqueous layer acidified to $\mathrm{pH} \sim 3$ with concentrated $\mathrm{HCl}$. The product precipitated as an almost white solid. After filtration and washing with water, the solid was dried $(0.85 \mathrm{~g}, 97 \%)$. ${ }^{1} \mathrm{H}$ NMR (200 MHz, DMSO-d $): \delta 2.39(3 \mathrm{H}, \mathrm{s}), 7.83(1 \mathrm{H}, \mathrm{dd}$, $J 2.3$ and $8.2 \mathrm{~Hz}), 8.37(1 \mathrm{H}, \mathrm{d}, J 8.0 \mathrm{~Hz}), 8.39(1 \mathrm{H}, \mathrm{dd}, J 2.1$ and $8.3 \mathrm{~Hz}), 8.48(1 \mathrm{H}, \mathrm{d}, J 8.3 \mathrm{~Hz}), 8.58(1 \mathrm{H}, \mathrm{d}, J 2.3 \mathrm{~Hz})$, $9.14(1 \mathrm{H}, \mathrm{d}, J 2.1 \mathrm{~Hz})$; IR (KBr) $v_{\max } / \mathrm{cm}^{-1}: 3432,1875,1702$, 1593, 1556, 1468, 1370, 1262, 1220, 1138, 1049, 839, 790, 742, 714; $\mathrm{MS}\left(\mathrm{EI}^{+}\right)$: 142.1 (25), 169.1 (27), 214.2 (100).

\section{5-(Chlorocarbonyl)-5'-methyl-2,2-bipyridine (9)}

Compound $\mathbf{8}(0.83 \mathrm{~g} ; 3.88 \mathrm{mmol})$ and $20 \mathrm{~mL}$ of thionyl chloride were refluxed for $3.5 \mathrm{~h}$. The excess thionyl chloride was distilled off and the pale yellow solid was dried under vacuum for two hours. The yield was quantitative and the product was used immediately in the subsequent reaction. IR (KBr) $v_{\text {max }} / \mathrm{cm}^{-1}: 1717,1594,1546,1378,1220,1128$, 847, 786. 
5-Methyl-5'-(N-methylhydroxamic)-2,2-bipyridine (10)

A mixture of $N$-methyl hydroxylammonium hydrochoride $\left(3.5 \mathrm{~mL}\right.$ of an aqueous solution $4 \mathrm{~mol} \mathrm{~L}^{-1}$; $14.1 \mathrm{mmol}$ ) with $\mathrm{NaOH}$ ( $3.5 \mathrm{~mL}$ of an aqueous solution 3.5 $\left.\mathrm{mol} \mathrm{L}^{-1} ; 12.3 \mathrm{mmol}\right)$ was added to compound $9(0.9 \mathrm{~g}, 3.88$ $\mathrm{mmol}$ ) at room temperature, while stirring. The mixture was stirred overnight. The suspension was adjusted until $\mathrm{pH} 7$, the white solid obtained was collected, and washed with water and diethyl ether. The product was dried $(0.78$ g, 74\%). ${ }^{1} \mathrm{H}$ NMR (200 MHz, $\mathrm{CDCl}_{3}$ ): $\delta 2.42(3 \mathrm{H}, \mathrm{s}), 3.48$ $(3 \mathrm{H}, \mathrm{s}), 7.66(1 \mathrm{H}, \mathrm{dd}, J 2.1$ and $8.2 \mathrm{~Hz}), 7.99(1 \mathrm{H}, \mathrm{dd}, J 2.2$ and $8.3 \mathrm{~Hz}), 8.30(1 \mathrm{H}, \mathrm{d}, J 8.1 \mathrm{~Hz}), 8.38(1 \mathrm{H}, \mathrm{d}, J 8.3 \mathrm{~Hz})$, $8.52(1 \mathrm{H}, \mathrm{d}, J 2.1 \mathrm{~Hz}), 8.82(1 \mathrm{H}, \mathrm{d}, J 2.2 \mathrm{~Hz})$; IR $(\mathrm{KBr})$ $v_{\text {max }} / \mathrm{cm}^{-1}: 3358,2829,1604,1455,1423,1386,1220,1025$, 908, 836, 781, 739, 650; MS (EI'): 169.1 (62), 197.1 (100), 227.2 (12), 243.2 (5); Anal. calcd. for $\mathrm{C}_{13} \mathrm{H}_{13} \mathrm{~N}_{3} \mathrm{O}_{2}$ : C, 64.20; H, 5.35; N, 17.28. Found: C, 63.94; H, 5.34; N, 17.37 .

Synthesis of the complex $\left[\mathrm{Fe}^{2+}(4)_{3}\right](\mathrm{Cl})_{2}(\mathbf{1 1})$

Ligand 4 (1.0 g; $3.31 \mathrm{mmol}$ ) was added to a degassed (with a stream of nitrogen) aqueous solution of $\mathrm{FeCl}_{2}$ $(0.219 \mathrm{~g} ; 1.10 \mathrm{mmol})$ while stirring at room temperature. The color of the reactional mixture changed immediately to purple. The mixture was stirred for one hour at room temperature under nitrogen. After that, the mixture was filtered and the purple solution was rotary-evaporated. The microcrystalline solid was dissolved in a minimum amount of water and precipitated by addition of hot acetone. The solid was filtered, washed with small volumes of acetone $(5 \times 20 \mathrm{~mL})$ and dried to give dark violet crystals $(1.03 \mathrm{~g}$; $90 \%$ yield). This complex is only soluble in water and methanol with very small amount of water. ${ }^{31}{ }^{1} \mathrm{H}$ NMR (200 $\left.\mathrm{MHz}, \mathrm{D}_{2} \mathrm{O}\right): \delta 3.09(18 \mathrm{H}, \mathrm{s}), 7.60(6 \mathrm{H}, \mathrm{s}), 8.22(6 \mathrm{H}, \mathrm{d}, J 7.84$ $\mathrm{Hz}), 8.54(6 \mathrm{H}, \mathrm{d}, J 7.84 \mathrm{~Hz})$; IR $(\mathrm{KBr}) v_{\max } / \mathrm{cm}^{-1}: 3339$, 3060, 2853, 1721, 1632, 1384, 1223, 1184, 1136, 1083, 1045, 913, 851, 741, 565; MS (FAB $\left.{ }^{+}\right): 997.1$ (50\%), 961.1 (100\%); $\mathrm{MS}\left(\mathrm{ESI}^{+}\right)$: $997.2(5 \%), 481.4(100 \%)$; Anal. calcd. for $\mathrm{C}_{42} \mathrm{H}_{42} \mathrm{~N}_{12} \mathrm{O}_{12} \mathrm{FeCl}_{2}: \mathrm{C}, 48.80 ; \mathrm{H}, 4.07 ; \mathrm{N}, 16.27$. Found: $\mathrm{C}, 48.92 ; \mathrm{H}, 4.05 ; \mathrm{N}, 16.34$.

Synthesis of the complex $\left[\mathrm{Fe}^{2+}\left(\mathrm{Fe}^{3+}\right)_{2}\left(4^{2-}\right)_{3}\right](\mathrm{Cl})_{2}(12)$

A solution of $\mathrm{FeCl}_{3}(66.5 \mathrm{mg}, 0.246 \mathrm{mmol})$ in methanol $(9 \mathrm{~mL})$ was added while stirring to a solution of $\mathbf{1 1}$ $(127 \mathrm{mg}, 0.123 \mathrm{mmol})$ in water $(15 \mathrm{~mL})$. The color of the solution immediately changed from purple to brownish red. The mixture was stirred at room temperature for one hour. The resultant solution was chromatographied on a Sephadex column. The fraction corresponding to the product was collected and was rotary-evaporated. The resultant solid was dried (black solid; $112 \mathrm{mg}$; 80\%). The EPR spectrum for the solution (methanol:water 4:1; $\mathrm{pH}$ 6.2) at liquid $\mathrm{N}_{2}$ temperature $(77 \mathrm{~K})$, as also for a solid sample of 12, showed a line having $g=4.3$. IR $(\mathrm{KBr}) v_{\max } / \mathrm{cm}^{-1}$ : 3405, 1719, 1607, 1435, 1384, 1202, 1135, 1089, 961, 848, 752, 704; Anal. calcd. for $\mathrm{C}_{42} \mathrm{H}_{36} \mathrm{~N}_{12} \mathrm{O}_{12} \mathrm{Fe}_{3} \mathrm{Cl}_{2}: \mathrm{C}, 44.27 ; \mathrm{H}$, 3.16; N, 14.76. Found: C, 44.36; H, 3.19; N, 14.85 .

Synthesis of the complex $\left[\left(\mathrm{Fe}^{3+}\right)_{2}\left(4^{2-}\right)_{3}\right](13)$

A suspension of $4(0.0401 \mathrm{~g} ; 0.133 \mathrm{mmol})$ in $10 \mathrm{~mL}$ of water was stirred. After that, $\mathrm{FeCl}_{3}(0.0144 \mathrm{~g} ; 0.0885 \mathrm{mmol})$ was added drop by drop as a solution $9.94 \times 10^{-3} \mathrm{~mol} \mathrm{~L}^{-1}$ in methanol. The solid dissolved immediately and a wine solution was observed. The reactional mixture was stirred for one hour and it was then chromatographied on a Sephadex column. The solvent was removed and the solid was dried $(0.0327 \mathrm{~g} ; 73 \%)$. EPR spectrum for the frozen solution (methanol:water 4:1; pH 6.2; $77 \mathrm{~K}$ ) showed a line having $g=4.3$. IR $(\mathrm{KBr}) v_{\max } / \mathrm{cm}^{-1}: 3421,2360,1719,1610$, 1435, 1384, 1205, 1087, 1040, 962, 851, 702, 672; Anal. calcd. for $\mathrm{C}_{42} \mathrm{H}_{36} \mathrm{~N}_{12} \mathrm{O}_{12} \mathrm{Fe}_{2}: \mathrm{C}, 49.82 ; \mathrm{H}, 3.56 ; \mathrm{N}, 16.61$. Found: C, 50.02; H, 3.54; N, 16.68 .

Synthesis of the complexes $\left[\mathrm{Fe}^{2+}(\mathbf{1 0})_{3}\right](\mathrm{Cl})_{2}(\mathbf{1 4 a}, \boldsymbol{b})$

Ligand 10 (0.100 g; $0.411 \mathrm{mmol})$ was suspended in degassed water $(10 \mathrm{~mL})$ and $\mathrm{FeCl}_{2}(0.0174 \mathrm{~g} ; 0.137 \mathrm{mmol})$ was added while stirring at room temperature. The solid was solubilized and the color of the reactional mixture immediately changed to purple. The solution was stirred for one hour, filtered and the solvent was rotary-evaporated. The resultant dark purple microcrystalline solid was dried ( $0.101 \mathrm{~g} ; 86 \%$ yield). The ${ }^{1} \mathrm{H}$ NMR spectrum revealed the presence of two isomers, $14 \mathbf{a}$ and $\mathbf{1 4 b}$. ${ }^{1} \mathrm{H}$ NMR $(400 \mathrm{MHz}$, $\mathrm{CD}_{3} \mathrm{OD}: \mathrm{D}_{2} \mathrm{O} 4: 1$ ): $\delta 2.23$ (s), 2.49 (s), 3.26 (s), 3.27 (s), $3.43(\mathrm{~s}), 7.32(3 \mathrm{H}, \mathrm{m}), 7.75(3 \mathrm{H}, \mathrm{m}) ; 8.06(3 \mathrm{H}, \mathrm{m}), 8.43(3 \mathrm{H}$, $\mathrm{m}), 8.61-8.68(6 \mathrm{H}, \mathrm{m})$. The COSY H-H spectrum showed the following correlations: methyl group bonded to aromatic system with H-3', H-4' and H-6', H-3'/H-4', H3'/H6', H-4'/H-6', H-3/H-4, H-3/H-6 and H-4/H-6. Anal. calcd. for $\mathrm{C}_{39} \mathrm{H}_{39} \mathrm{~N}_{9} \mathrm{O}_{6} \mathrm{FeCl}_{2}: \mathrm{C}, 54.69 ; \mathrm{H}, 4.56 ; \mathrm{N}, 14.72$. Found: C, 54.40; H, 4.58; N, 14.78 .

Synthesis of the complexes $\left[\mathrm{Fe}^{2+} \mathrm{Fe}^{3+}\left(\mathbf{1 0}^{-}\right)_{3}\right](\mathrm{Cl})_{2}(\mathbf{1 5 a}, \boldsymbol{b})$

These complexes were only prepared in solution. The EPR spectrum for the frozen solution (methanol:water 4:1; $\mathrm{pH}$ 6.2) of 15a,b (77 K) showed a broad line having $g=4.3$. 
Synthesis of the complex $\left[\mathrm{Fe}^{3+}(\mathbf{1 0})_{3}\right]\left(\mathrm{Cl}^{-}\right)_{2}(\mathbf{1 6})$

This complex was only prepared in solution. Ligand 10 (0.00292 g; $0.012 \mathrm{mmol})$ was added to a solution of $\mathrm{FeCl}_{3} 5.24 \times 10^{-4} \mathrm{~mol} \mathrm{~L}^{-1}$ in $16 \mathrm{~mL}$ methanol and $4 \mathrm{~mL}$ buffer MES ( $\left.\mathrm{pH}=6.20,50 \mathrm{mmol} \mathrm{L}^{-1}\right)$. An orange solution was immediately formed. $\lambda_{\max }=424 \mathrm{~nm} ; \varepsilon_{\max }=3106 \mathrm{~L} \mathrm{~mol}^{-1}$ $\mathrm{cm}^{-1}$; the EPR spectrum of this frozen solution $(77 \mathrm{~K})$ showed a very sharp line having $g=4.3$.

Synthesis of the complex $\left[\mathrm{Fe}^{2+}(\mathbf{1 0})_{3}\right]\left(\mathrm{Cl}^{-}\right)_{2}(\mathbf{1 4 a})$

This complex was prepared only in solution for NMR measurements. Ligand $\mathbf{1 0}\left(0.00237 \mathrm{~g} ; 9.7 \times 10^{-6} \mathrm{~mol}\right)$ was dissolved in $0.5 \mathrm{~mL}$ of a $\mathrm{CD}_{3} \mathrm{OD}: \mathrm{D}_{2} \mathrm{O}(4: 1)$ mixture. After that, $\mathrm{FeCl}_{3}$ was added $\left(5.45 \times 10^{-4} \mathrm{~g} ; 3.36 \times 10^{-6} \mathrm{~mol}\right)$ and an orange color appeared. $\mathrm{FeCl}_{2}$ was then added $(36.5 \mathrm{~mL}$ from a $\mathrm{D}_{2} \mathrm{O}$ stock solution $0.092 \mathrm{~mol} \mathrm{~L}^{-1}$ ). Finally, after 10 minutes, $2 \mathrm{mg}\left(1.13 \times 10^{-5} \mathrm{~mol}\right)$ of ascorbic acid was added to the NMR tube. ${ }^{1} \mathrm{H}$ NMR (400 MHz): $\delta 2.23(9 \mathrm{H}, \mathrm{s}), 3.24$ $(9 \mathrm{H}, \mathrm{s}), 7.32(3 \mathrm{H}, \mathrm{m}), 7.75(3 \mathrm{H}, \mathrm{m}) ; 8.06(3 \mathrm{H}, \mathrm{m}), 8.43(3 \mathrm{H}$, $\mathrm{m}), 8.61-8.68(6 \mathrm{H}, \mathrm{m})$. The COSY H-H spectrum showed the following correlations: methyl group bonded to aromatic system with H-3', H-4' and H-6', H-3'/H-4', H3'/H6', H-4'/H-6', H-3/H-4, H-3/H-6 and H-4/H-6.

\section{$p K_{a}$ determinations}

The $p K_{a}$ titrations were performed in aqueous $0.1 \mathrm{~mol} \mathrm{~L}^{-1}$ tetramethylammonium chloride with magnetic stirring, using a water-jacket equipped sealed cell in which a strong argon stream was maintained. The medium was thermostated at $25.0 \pm 0.1^{\circ} \mathrm{C}$ with circulating water through the outer jacket. Standard $0.1 \mathrm{~mol} \mathrm{~L}^{-1} \mathrm{CO}_{2}$-free $\mathrm{NaOH}$ was delivered from a microburette. Potential measurements were performed in millivolt mode with the use of a glass electrode. The potential versus volume data were analysed with Superquad. ${ }^{32}$

\section{Stoichiometry determinations}

The experiments for stoichiometry determinations were performed with the mole-ratio method ${ }^{33}$ and with the method of continuous variations (Job's method). ${ }^{34}$

The mole-ratio determinations were made as follows: a solution of complex $\mathbf{1 1}\left(2.5 \times 10^{-4} \mathrm{~mol} \mathrm{~L}^{-1}\right)$ was prepared in a 4:1 (v:v) methanol:buffer MES $\left(30 \times 10^{-3} \mathrm{~mol} \mathrm{~L}^{-1}\right.$; $\left.\mathrm{pH} 6.2\right)$ mixture. A volume of $1 \mathrm{~mL}$ was transferred from this solution to a quartz cuvette sealed with a rubber septum. This sealed solution was bubbled with argon and the sample was placed in the UV-Vis apparatus, with the cell- compartment thermostated at $25^{\circ} \mathrm{C}$. A baseline was made with this initial solution in order to verify the appearance of the band at ca. $420 \mathrm{~nm}$. Small aliquots of a $\mathrm{FeCl}_{3}$ stock solution $\left(8.43 \times 10^{-3} \mathrm{~mol} \mathrm{~L}^{-1}\right)$ in methanol were then transferred to the cuvette with a microsyringe with intervals of five minutes between each addition. The mixture was stirred after each addition and the maximum in absorbance at $426 \mathrm{~nm}$ was read. The same experiment was performed with the titrations of $\mathbf{1 1}$ with $\mathrm{FeCl}_{3}$ in the mixture having $\mathrm{pH} 4.5$ (buffer pyridine- $\mathrm{HCl} 30 \times 10^{-3} \mathrm{~mol} \mathrm{~L}^{-1}$ ). The titrations of ligand 4 with $\mathrm{FeCl}_{3}$ were also made in a similar manner.

Job plots were performed for the complex formed with 11 and $\mathrm{Fe}^{3+}$. These studies were performed at $25^{\circ} \mathrm{C}$ in $4: 1$ (v:v) methanol:buffer $\left(30 \times 10^{-3} \mathrm{~mol} \mathrm{~L}^{-1}\right)$ mixture. The stock solutions of $\mathbf{1 1}$ and $\mathrm{Fe}^{3+}$ in the experiments at $\mathrm{pH} 6.2$ had concentrations of $2.5 \times 10^{-4} \mathrm{~mol} \mathrm{~L}^{-1}$. Two sets of experiments were made at $\mathrm{pH} 4.5$, with stock solutions of $3.6 \times 10^{-4} \mathrm{~mol} \mathrm{~L}^{-1}$ and $4.9 \times 10^{-4} \mathrm{~mol} \mathrm{~L}^{-1}$. The absorbances were read at $\lambda_{\max }$ equal to $426 \mathrm{~nm}$.

\section{EDTA competition experiments}

Buffered stock solutions of $\mathrm{FeCl}_{3}\left(1.85 \times 10^{-3} \mathrm{~mol} \mathrm{~L}^{-1}\right)$, $11\left(6.01 \times 10^{-4} \mathrm{~mol} \mathrm{~L}^{-1}\right)$ and EDTA $\left(7.17 \times 10^{-4} \mathrm{~mol} \mathrm{~L}^{-1}\right)$ were prepared in a $4: 1(\mathrm{v}: \mathrm{v})$ methanol:water mixture and the $\mathrm{pH}$ 4.5 was kept constant with pyridine $\left(30 \times 10^{-3} \mathrm{~mol} \mathrm{~L}^{-1}\right)$. Ionic strength was also kept constant with the use of tetrabutylammonium tetrafluoroborate $0.1 \mathrm{~mol} \mathrm{~L}^{-1}$ (the use of $\mathrm{KNO}_{3}$ provoked the precipitation of the solutions after some hours of experiment). Other solutions were prepared having $\left[\mathrm{Fe}^{3+}\right]=3.06 \times 10^{-4} \mathrm{~mol} \mathrm{~L}^{-1}$; $[\mathrm{EDTA}]=0.58-3.48 \times 10^{-4}$ mol L-1 $[\mathbf{1 1}]=2.11-4.23 \times 10^{-4} \mathrm{~mol} \mathrm{~L}^{-1}$. These solutions were kept for one week at $25^{\circ} \mathrm{C}$ in a thermostated bath to allow equilibration and their UV-Vis spectra were then taken. The molar absorptivities for complexes $\mathbf{1 1}$ and $\mathbf{1 2}$ at 426 $\mathrm{nm}$ and $\mathrm{pH} 4.5$ were calculated as 1997 and $4012 \mathrm{~L} \mathrm{~mol}^{-1}$ $\mathrm{cm}^{-1}$ per $\mathrm{Fe}^{3+}$, respectively. Competition experiments took into account the following equilibrium (1),

$2 \mathrm{Fe}(\mathrm{EDTA})^{-}+\mathbf{1 1} \stackrel{K_{\text {eq }}}{\rightleftharpoons} \mathbf{1 2}+2 \mathrm{H}_{2}(\mathrm{EDTA})^{2-}+2 \mathrm{H}^{+}$

whose equilibrium constant $\left(K_{e q}\right)$ can be calculated by means of equation (2).

$K_{e q}=4 \alpha^{3} c_{H+}^{2} /\left(c_{11}-\alpha\right)\left(c_{F e(E D T A-)}-2 \alpha\right)^{2}$

Since $\mathbf{1 1}$ and $\mathbf{1 2}$ are the only iron-containing and only absorbing species, $\alpha$, the fraction of the iron present as $\mathbf{1 2}$ complex, is given by equation (3),

$\alpha=\left(A-\varepsilon_{11} c_{11}-\varepsilon_{F e(E D T A-)} c_{F e(E D T A-)}\right) /\left(\varepsilon_{12}-2 \varepsilon_{F e(E D T A-)}-\varepsilon_{11}\right)(3)$ 
$A$ being the absorbance of the solution at $426 \mathrm{~nm}, c$ and $\varepsilon$ the molar concentration and molar absorptivity respectively at $426 \mathrm{~nm}$ for the species present in equilibrium. The subscripts 11 and 12 are related with complexes 11 and 12, respectively while $\mathrm{Fe}(E D T A)^{-}$refers to the complex formed with $\mathrm{Fe}^{3+}$ and EDTA. Since the solutions of $\mathrm{Fe}(\mathrm{EDTA})^{-}$are colorless at $426 \mathrm{~nm}$, we considered $\varepsilon_{F(E D T A-)}$ equal to zero in the calculations. With the use of $10^{25.0}$ as the formation constant of Fe(EDTA) $)^{-35}$ $\beta_{1}$ could be averaged for the reaction represented by equation (4).

$2 \mathrm{Fe}^{3+}+11 \stackrel{\beta_{1}}{\rightleftharpoons} 12+6 \mathrm{H}^{+}$

\section{Results and Discussion}

\section{Synthesis of the ligands and the complexes}

The 5,5'-disubstituted-2,2'-bipyridines were synthesized according to the synthetic routes described in Schemes 1 and 2. Ligands $\mathbf{4}$ and 6-10 are new compounds and were fully characterized.

The first reaction involved the coupling of $\beta$-picoline with the use of Raney-nickel, resulting in 5,5'-dimethylbipy (1). ${ }^{26,27}$ This compound was oxidized with potassium permanganate in aqueous solution (reflux for $16 \mathrm{~h}$ ), resulting in the diacid 2 in good yield. ${ }^{28}$ The latter was transformed into the corresponding bis-acid chloride (3) with thionyl chloride during reflux ${ }^{29}$ in quantitative yield. Reaction of $\mathbf{3}$ with $N$-methylhydroxylamine yielded ligand $4(85 \%)$.

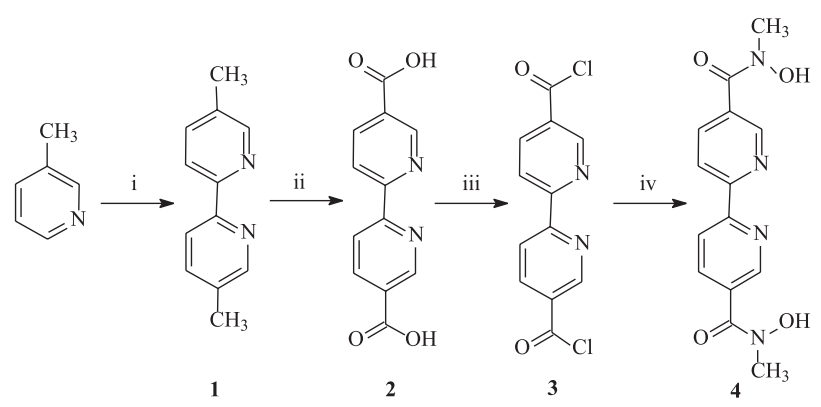

Scheme 1. Reagents: i, Raney nickel; ii, $\mathrm{KMnO}_{4}$; iii, $\mathrm{SOCl}_{2}$; iv, $\mathrm{NHCH}_{3} \mathrm{OH}$.

The synthetic pathway shown in Scheme 2 gives access in good yield to non-symmetrical 5,5'-disubstituted 2,2'bipys. Diazotation of 2-amino-5-methylpyridine and subsequent reaction with bromine in the presence of a concentrated solution of hydrobromic acid resulted in $\mathbf{5} .{ }^{30}$ Stannylation with $n$-butyl lithium and trimethyltin chloride $^{36}$ yielded compound $\mathbf{6}$, which was then coupled in very good yield with ethyl 6-chloronicotinate in toluene through a modification of the literature procedure ${ }^{37}$ using $\left[\mathrm{Pd}\left(\mathrm{PPh}_{3}\right)_{4}\right]$ as a catalyst ${ }^{23}$ to give the monoester 7 . Hydrolysis of 7 with $\mathrm{NaOH}$ aqueous methanol gave the corresponding acid $\mathbf{8}$ almost quantitatively. The acid was refluxed with thionyl chloride to yield quantitatively the acyl chloride 9 , which was reacted with $N$-methyl hydroxylamine to give ligand $\mathbf{1 0}$ in good yield (74\%).

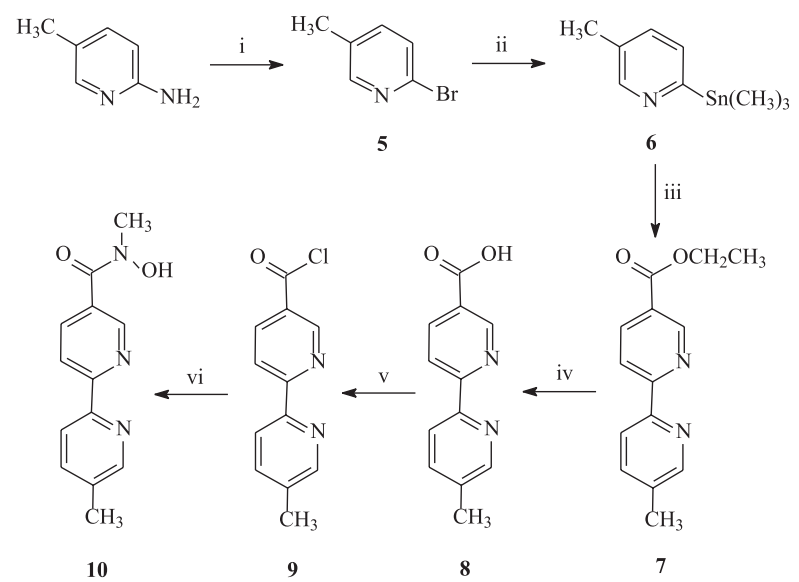

Scheme 2. Reagents: i, aqueous $\mathrm{HBr} / \mathrm{Br}_{2}, \mathrm{NaNO}_{2}$; ii, (a) $n$-butyl lithium, (b) $\left(\mathrm{CH}_{3}\right)_{3} \mathrm{SnCl}$; iii, 2-chloro-5-ethylnicotinate, $\left[\mathrm{Pd}\left(\mathrm{PPh}_{3}\right)_{4}\right]$ (12 mol \%); iv, aqueous $\mathrm{NaOH}$, methanol; v, $\mathrm{SOCl}_{2}$, vi, $\mathrm{NHCH}_{3} \mathrm{OH}$.

The $\mathrm{Fe}^{2+}$ complexes $\mathbf{1 1}$ and $\mathbf{1 4}$ of the bipy ligands 4 and 10 were obtained by stirring the ligand with $\mathrm{FeCl}_{2}$ in degassed water in the proportion metal:ligand $1: 3{ }^{38}$

$p K_{a}$ values

A first question that emerges is whether the complexation of ligands $\mathbf{4}$ and $\mathbf{1 0}$ with $\mathrm{Fe}^{2+}$ affects the physicochemical properties of the $N$-methyl hydroxamic acid groups. If the metal ion causes, for instance, changes in the ionization constants of these groups, it will influence the capability of the complex formed to act as a metalloexoreceptor. Therefore, $\mathrm{p} K_{a}$ values of ligands $\mathbf{4}$ and $\mathbf{1 0}$ and their respective $\mathrm{Fe}^{2+}$ complexes 11 and 14a,b were obtained by potentiometric titrations (Table 1). For comparison, the $\mathrm{p} K_{a}$ value for the $N$-methyl acetohydroxamic acid was determined under the same conditions, giving a value close to those obtained for the bipy ligands $\mathbf{4}$ and $\mathbf{1 0}$. The values determined for the corresponding $\mathrm{Fe}^{2+}$ complexes $\mathbf{1 1}$ and $\mathbf{1 4 a , b}$ show that the binding of the metal ion induces a significant change in the $\mathrm{p} K_{a}$ of the hydroxamic acid group. Thus, the $\mathrm{p} K_{a}$ values of 8.2 and 9.1 for ligand 4 decrease by about two units to 6.2 and 7.1 , indicating the important role of the metal ion. 


\section{Self-assembly of a trimetallic complex}

Along the lines presented in the Introduction, ligand 4 was first complexed by $\mathrm{FeCl}_{2}$ and the $\mathrm{Fe}^{2+}$-tris(bipyridine) complex formed (11) was titrated with a $\mathrm{FeCl}_{3}$ solution, according to Scheme 3, to yield complex 12. The formation of this trinuclear structure was followed by UV-Vis and EPR spectroscopies.

Complex 11 presents an absorption band at $550 \mathrm{~nm}$ due to metal to ligand charge transfer (MLCT). Addition of $\mathrm{FeCl}_{3}$ into a buffered solution ( $\mathrm{pH}$ 6.2) of this complex leads to the appearance of a new band in the visible region of the spectrum. The color change is complete within a few minutes (ca. 4 minutes). This band, at $426 \mathrm{~nm}$, is characteristic of the ligand to metal charge transfer in tris(hydroxamato)Fe ${ }^{3+}$ complexes. ${ }^{39}$ The molar absorptivity of $2864 \mathrm{~L} \mathrm{~mol}^{-1} \mathrm{~cm}^{-1}$ per $\mathrm{Fe}^{3+}$ at this $\mathrm{pH}$ agrees with the data from the literature ${ }^{20,39}$ and for the tris(hydroxamato) $\mathrm{Fe}^{3+}$ complex prepared under the same conditions from ligand $10\left(\lambda_{\max }=424 \mathrm{~nm} ; \varepsilon_{\max }=3106 \mathrm{~L} \mathrm{~mol}^{-1} \mathrm{~cm}^{-1}\right)$. A plot of absorbance at $426 \mathrm{~nm}$ as a function of added $\mathrm{Fe}^{3+}$ equivalents indicates a 1:2 11: $\mathrm{Fe}^{3+}$ ratio (Figure 1a).

According to the literature, the complexation of hydroxamic acids with $\mathrm{Fe}^{3+}$ in more acid $\mathrm{pH}$ values leads to the formation of mono- and bis(hydroxamato) $\mathrm{Fe}^{3+}$ complexes. ${ }^{39}$ This was confirmed when the complexation of 4 with $\mathrm{Fe}^{3+}$ was performed at $\mathrm{pH} 4.5$ (methanol/water 4:1). The appearance of a band at $465 \mathrm{~nm}$ was observed $\left(\varepsilon_{\max }=1882 \mathrm{~L} \mathrm{~mol}^{-1} \mathrm{~cm}^{-1}\right)$, corresponding to the formation of bis(hydroxamato) $\mathrm{Fe}^{3+}$, in agreement with the literature. ${ }^{21,39}$ The addition of $\mathrm{Fe}^{3+}$ to a solution of complex 11 under the same conditions led also to the appearance of a band at $c a .420 \mathrm{~nm}\left(\varepsilon_{\max }=4012 \mathrm{~L} \mathrm{~mol}^{-1} \mathrm{~cm}^{-1}\right.$ per Fe$\left.{ }^{3+}\right)$ and to the same stoichiometry 1:2 11: $\mathrm{Fe}^{3+}$ (Figure 1b).

Job plots of absorbance values at $426 \mathrm{~nm}$ both at $\mathrm{pH}$ 4.5 (pyridine buffer) and 6.2 (MES buffer) showed also a maximum absorbance for a 1:2 11: $\mathrm{Fe}^{3+}$ ratio (Figure 2). The data indicate the formation of tris(hydroxamato) $\mathrm{Fe}^{3+}$ under these conditions, in agreement with the fact that the complexation decreases the $\mathrm{p} K_{a}$ values for the hydroxamic acid groups, making them available to form the tris(hydroxamato) $\mathrm{Fe}^{3+}$ complex after the first complexation with the $\mathrm{Fe}^{2+}$ ion. This result highlights the double role of the $\mathrm{Fe}^{2+}$ ion in the process, not only organizing the hydroxamic acid groups for the second complexation with the $\mathrm{Fe}^{3+}$ ion, but also inducing favorable conditions for this sequential binding in a hierarchical fashion.

The experiments also demonstrated that complex $\mathbf{1 1}$ is

Table 1. $\mathrm{p} K_{a}$ values for the $N$-methyl hydroxamic acids ${ }^{\mathrm{a}}$

\begin{tabular}{|c|c|c|c|c|c|c|}
\hline Compound & $\mathrm{p} K_{a l}$ & $\mathrm{p} K_{a 2}$ & $\mathrm{p} K_{a 3}$ & $\mathrm{p} K_{a 4}$ & $\mathrm{p} K_{a 5}$ & $\mathrm{p} K_{a 6}$ \\
\hline$N$-methylacetohydroxamic acid & 8.5 & - & - & - & - & - \\
\hline 4 & 8.2 & 9.1 & - & - & - & - \\
\hline 10 & 8.3 & - & - & - & - & - \\
\hline $11^{\mathrm{b}}$ & 6.2 & 7.1 & 7.9 & 8.6 & 9.2 & 9.9 \\
\hline $14 a, b^{b}$ & 6.5 & 8.2 & 9.8 & - & - & - \\
\hline
\end{tabular}

${ }^{\text {a }}$ Ionic strength $=0.1 \mathrm{~mol} \mathrm{~L}^{-1} ; 25{ }^{\circ} \mathrm{C}$; ${ }^{\mathrm{b}}$ Experiment performed under strong argon stream in order to avoid the oxidation of the complex.

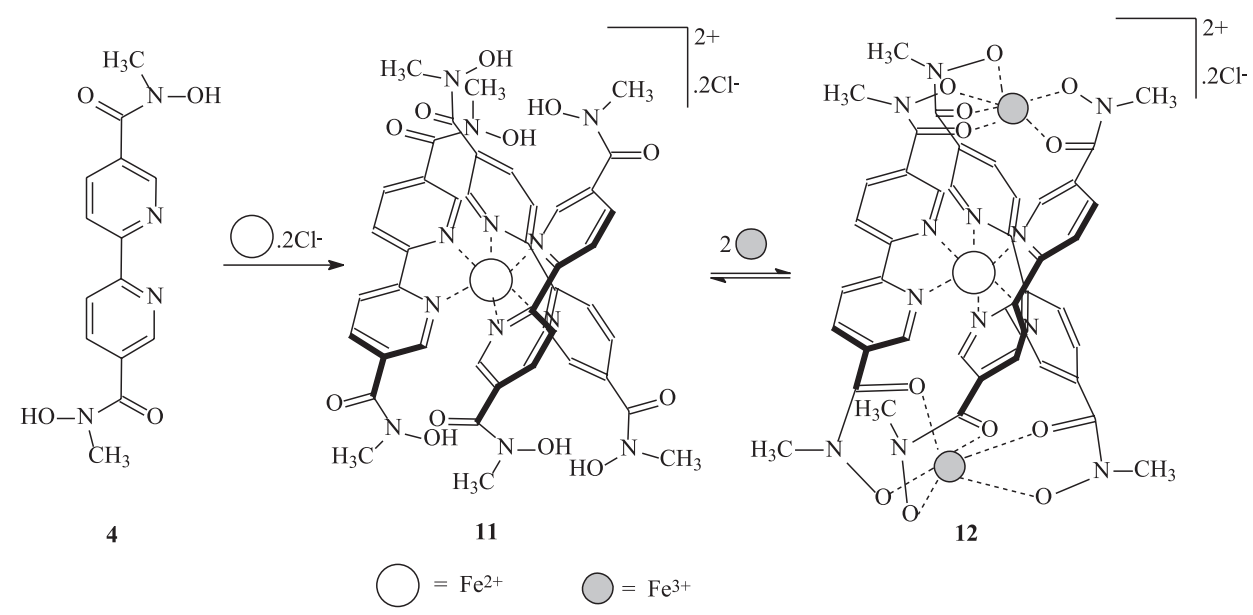



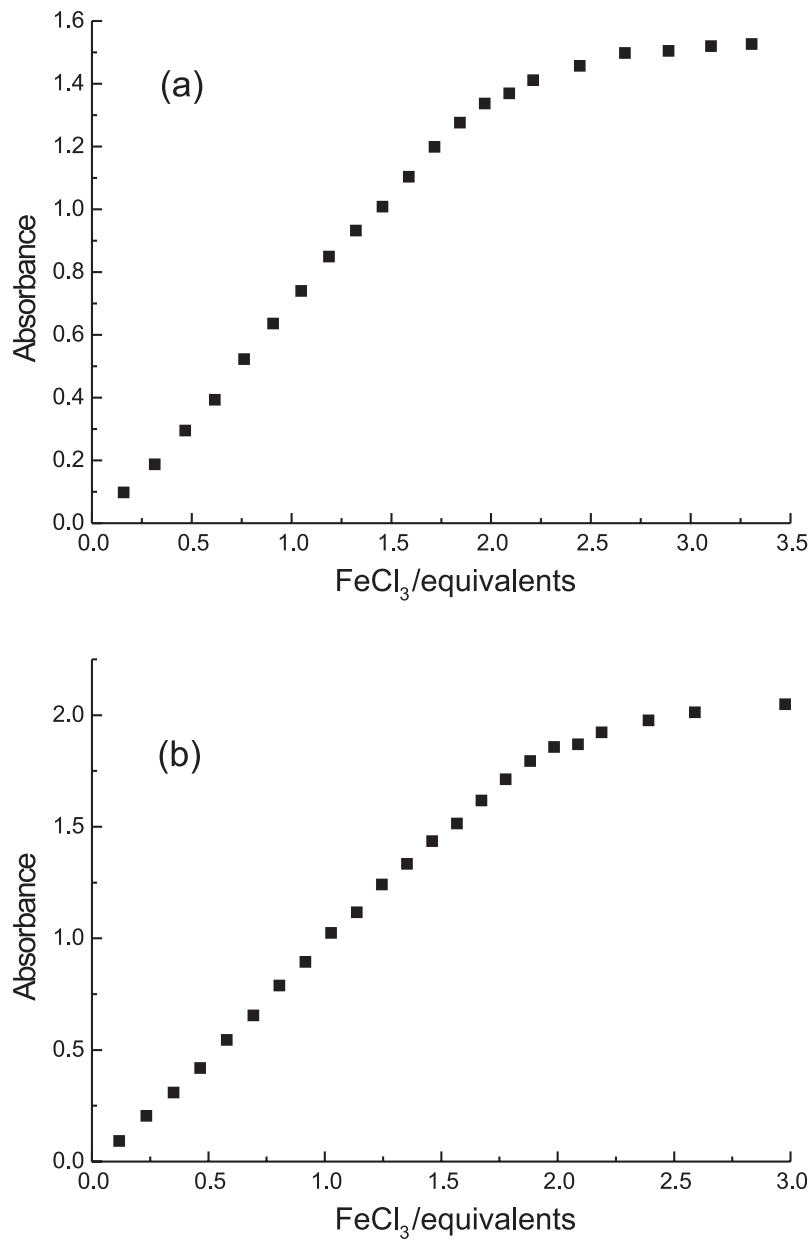

Figure 1. a) Addition of $\mathrm{FeCl}_{3}$ to a solution of compound 11 $\left(2.5 \times 10^{-4} \mathrm{~mol} \mathrm{~L}^{-1}\right)$ in $4: 1$ methanol: buffer MES $30 \times 10^{-3} \mathrm{~mol} \mathrm{~L}^{-1}(\mathrm{pH}$ 6.2). The absorbance values were collected at $426 \mathrm{~nm}$; b) Addition of $\mathrm{FeCl}_{3}$ to a solution of compound $\mathbf{1 1}\left(2.5 \times 10^{-4} \mathrm{~mol} \mathrm{~L}^{-1}\right)$ in $4: 1$ methanol: buffer pyridine-HCl $30 \times 10^{-3} \mathrm{~mol} \mathrm{~L}^{-1}(\mathrm{pH} 4.5)$. The absorbance values were collected at $426 \mathrm{~nm}$

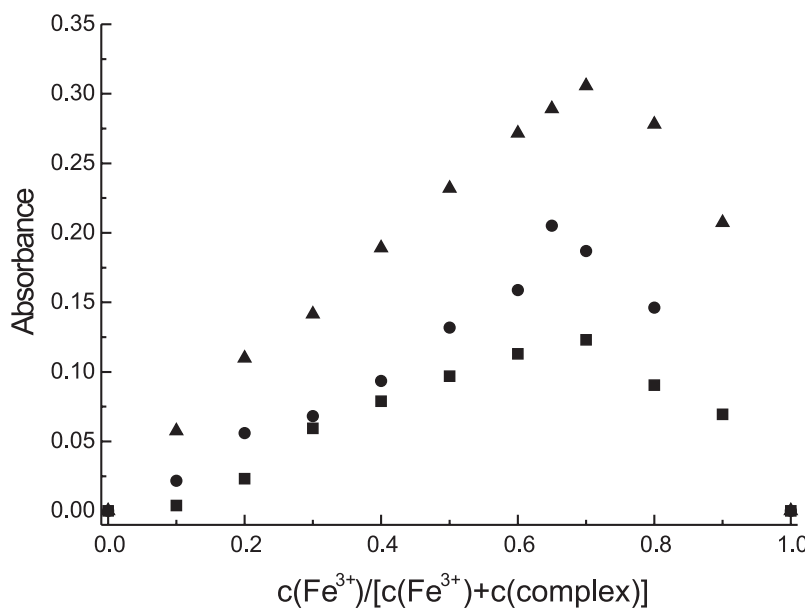

Figure 2. Job plot for the complex between 11 and $\mathrm{Fe}^{3+}$ (general conditions: $\lambda_{\text {max }}=426 \mathrm{~nm} ; 4: 1$ methanol:buffer $30 \times 10^{-3} \mathrm{~mol} \mathrm{~L}^{-1} ; 25^{\circ} \mathrm{C}$ ). - : buffer MES, pH 6.2, initial concentrations of $\mathbf{1 1}$ and $\mathrm{Fe}^{3+}\left(c_{i}\right)$ are equal to $2.5 \times 10^{-4} \mathrm{~mol} \mathrm{~L}^{-1} ; \bullet$ : buffer pyridine- $\mathrm{HCl}, \mathrm{pH} 4.5, \mathrm{c}_{\mathrm{i}}=3.6 \times 10^{-4}$ mol L ${ }^{-1} ; \boldsymbol{\Delta}$ : buffer pyridine-HCl, $\mathrm{pH} 4.5, c_{i}=4.9 \times 10^{-4} \mathrm{~mol} \mathrm{~L}^{-1}$. not stable at $\mathrm{pH}$ above 5.8 in the presence of oxygen. Under these conditions, the band at 550 decreases as a band develops at $426 \mathrm{~nm}$, characteristic of tris(hydroxamato) $\mathrm{Fe}^{3+}$ species. The final spectrum presents the same pattern for complex 12 above. The addition of ascorbic acid to these solutions, in order to reduce the $\mathrm{Fe}^{3+}$ ion, caused the reappearance of the original band at $550 \mathrm{~nm}$ in complex 11. The addition of $\mathrm{Fe}^{3+}$ to the starting complex $\mathbf{1 1}$ in the ratio 1:2 11: $\mathrm{Fe}^{3+}$, however, prevents the oxidation of $\mathrm{Fe}^{2+}$ bound to the bipy units. These results agree with data from literature ${ }^{40}$ since it has been well established that $\mathrm{Fe}^{2+}$ can be easily oxidized to $\mathrm{Fe}^{3+}$ in the presence of atmospheric oxygen, and that the rates of oxidation are highly dependent on $\mathrm{pH}$ and on the nature of the coordinating ligands.

These same conditions were also used to perform direct complexation of the hydroxamic acid groups of ligand $\mathbf{4}$ with $\mathrm{Fe}^{3+}$ (Scheme 4). Only a band in the visible region was observed $\left(\lambda_{\max }=426 \mathrm{~nm} ; \varepsilon_{\max }=3046 \mathrm{~L} \mathrm{~mol}^{-1} \mathrm{~cm}^{-1}\right)$. Subsequent addition of $\mathrm{Fe}^{2+}$ led to the appearance of the band at $550 \mathrm{~nm}$, corresponding to the formation of (bipy) ${ }_{3} \mathrm{Fe}^{2+}$, in agreement with the formation of the same trinuclear structure 12, independent of the sequence of metal ion addition.

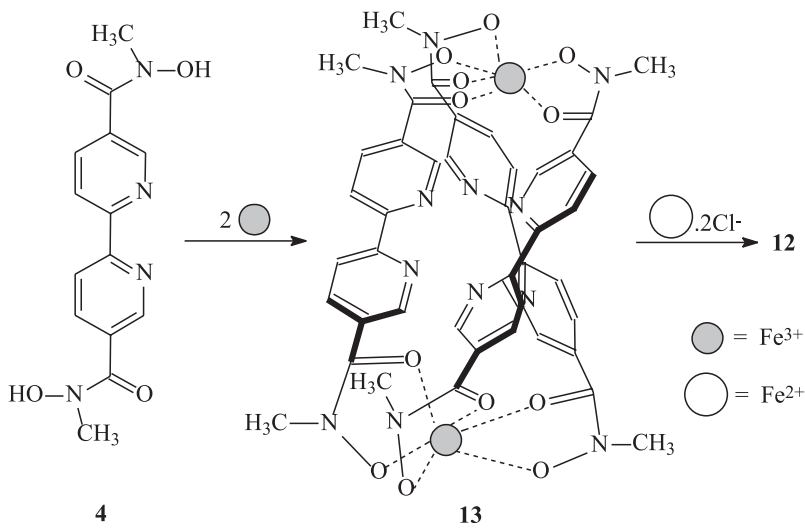

Scheme 4

Ligand competition experiments involving EDTA, complex 11, and $\mathrm{Fe}^{3+}$ were performed at $\mathrm{pH} 4.5$ (according to equation 1). The equilibrium constant $\left(K_{e q}\right)$ for equation 1 was calculated from spectra of solutions in which EDTA competed with $\mathbf{1 1}$ for $\mathrm{Fe}^{3+}$. This value, $K_{e q}=8.31 \times 10^{-9}$, represents the average of 6 values calculated at $\mathrm{pH} 4.5$. The competition constant $\left(K_{e q}\right)$ and the formation constant of FeEDTA ${ }^{-}$were used ${ }^{35}$ to calculate of the formation constant of complex 11, giving a value of $\log \beta=16.9$.

Complex 12 was also studied by EPR spectroscopy. EPR spectra for this complex in solid state (second derivative mode) and in frozen solution (4:1 
methanol:water; buffer MES $30 \times 10^{-3} \mathrm{~mol} \mathrm{~L}^{-1}$, pH 6.2; 77 $\mathrm{K}$ ) in first derivative mode provided further evidence for the proposed structure (Figure 3). A line showing $g=4.3$, characteristic for high spin $\mathrm{Fe}^{3+}$ in a rhombic site with oxygenated ligands around the metal ion, was obtained. The spectrum for the second derivative mode suggests that there is only one type of coordination site for $\mathrm{Fe}^{3+}$ in the complex.

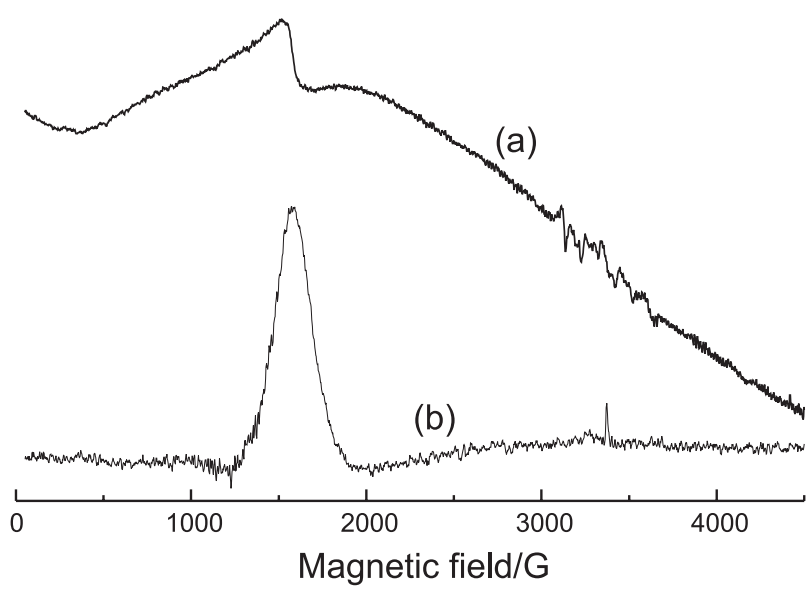

Figure 3. EPR spectra for complex 12 in (a) 4:1 methanol:water frozen ( $77 \mathrm{~K}$ ) mixture (buffer MES $30 \times 10^{-3} \mathrm{~mol} \mathrm{~L}^{-1}, \mathrm{pH}$ 6.2] and (b) in the second derivative mode for the solid sample at $77 \mathrm{~K}$.

Figure 4 depicts the EPR spectrum for an experiment of sequential complexation using first $\mathrm{Fe}^{3+}$ and then $\mathrm{Fe}^{2+}$ ions, in a 4:1 methanol:water frozen mixture (buffer MES $30 \times 10^{-3} \mathrm{~mol} \mathrm{~L}^{-1}, \mathrm{pH} 6.2$ ). The shape of the spectrum is similar to that observed for complex 12. Figure 4 shows also the spectrum for the reaction between ligand $\mathbf{4}$ with only $\mathrm{Fe}^{3+}$ ions, which displays the same pattern as the other two spectra. The similarities among the three spectra suggest that the complexation of $\mathbf{4}$ with $\mathrm{Fe}^{3+}$ leads to a structure reminiscent of $\mathbf{1 2}$, i.e., the suggested structure 13. The same experiments were performed with solutions at $\mathrm{pH} 4.5$ and gave the same results as those at $\mathrm{pH}$ 6.2, since this technique does not allow us to distinguish between bis- and tris(hydroxamate) $\mathrm{Fe}^{3+}$ complexes. Other considerations about the EPR spectra will be made below.

\section{Self-assembly of bimetallic architectures}

Ligand $\mathbf{1 0}$ is interesting as it explores the strategy of sequential complexation, since the complexation with $\mathrm{Fe}^{2+}$ and $\mathrm{Fe}^{3+}$ ions may yield in principle bimetallic architectures, with the added feature that a mixture of two isomers is expected if the complexation is performed with $\mathrm{Fe}^{2+}$ ions only. A ${ }^{1} \mathrm{H}$ NMR study, in $\mathrm{CD}_{3} \mathrm{OD}-\mathrm{D}_{2} \mathrm{O}$ (4:1), demonstrated the presence of signals corresponding to the

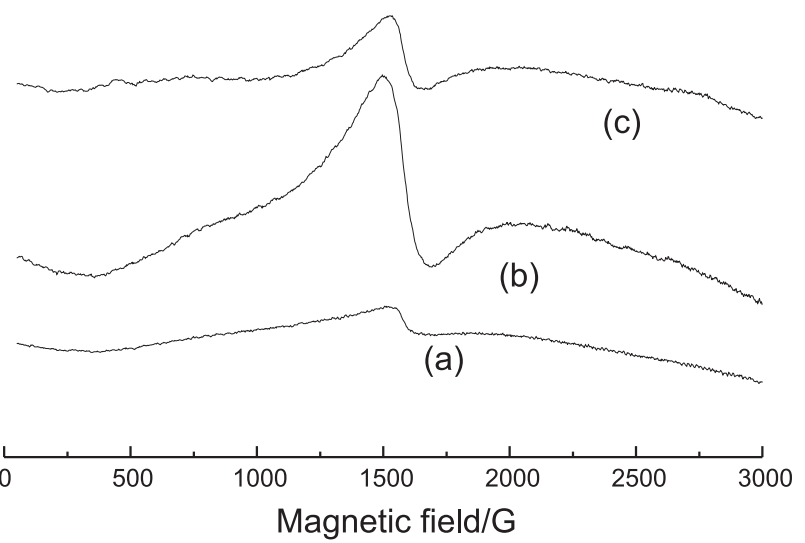

Figure 4. EPR spectra for: (a) complex 12; (b) an experiment of sequential complexation using firstly $\mathrm{Fe}^{3+}$ and after $\mathrm{Fe}^{2+}$ in the complexation of 4 (see Scheme 4); and (c) for the reaction between ligand 4 and $\mathrm{Fe}^{3+}$. All spectra were recorded in 4:1 methanol:water solution (buffer MES $30 \times 10^{-3} \mathrm{~mol} \mathrm{~L}^{-1}, \mathrm{pH}$ 6.2) and were taken at 77 $\mathrm{K}$ by freezing the samples in liquid nitrogen.

methyl protons on the pyridine ring $(\delta 2.23$ and 2.49$)$ and for the methyl protons from the hydroxamic acid groups $(\delta 3.26,3.27$ and 3.43$)$. The proportion of the two isomers, obtained by integration of the methyl signals, was $73 \%$ for $\mathbf{1 4 a}$ and $27 \%$ for $\mathbf{1 4 b}$ (Scheme 5).

If $\mathrm{Fe}^{3+}$ is added to the mixture of $\mathbf{1 4} \mathbf{a}$ and $\mathbf{1 4} \mathbf{b}$, UV-Vis studies suggest the formation of a mixture containing tris(hydroxamato) $\mathrm{Fe}^{3+}(\mathbf{1 5 a})$ and bis(hydroxamato) $\mathrm{Fe}^{3+}$ (15b), according to Scheme 5. A broad band in the visible region of the spectrum between 420 and $460 \mathrm{~nm}$ gives evidence for the mixture. No changes in the spectrum could be observed by heating at $40^{\circ} \mathrm{C}$ for several hours. It was not possible to follow complexation by ${ }^{1} \mathrm{H}$ NMR because of signal broadening (due to the presence of complexed paramagnetic $\mathrm{Fe}^{3+}$ ), but no changes occurred in the region of methyl protons under complexation (the disappearance of the protons at $\delta 2.49$ and 3.43 , that would characterize the transformation of the isomer $\mathbf{1 5 b}$ in $\mathbf{1 5 a}$, was not observed). In addition, complexed $\mathrm{Fe}^{3+}$ was reduced with ascorbic acid on heating and the resulting ${ }^{1} \mathrm{H}$ NMR spectrum was found to be the same as that of complex $\mathbf{1 4 a , b}$, with no change in the proportion of the two isomers.

Sequential complexation performed by changing the order of addition of the metal ions (Scheme 6) should yield only one of the two possible isomers. With initial addition of $\mathrm{Fe}^{3+}$ followed by the complexation with $\mathrm{Fe}^{2+}$, the first metal ion would organize the ligands, acting as a template and forming an adequate cavity for $\mathrm{Fe}^{2+}$. Thereafter, reduction of complexed $\mathrm{Fe}^{3+}$ by ascorbic acid should lead to decomplexation from its site. This strategy was verified by UV-Vis, ${ }^{1} \mathrm{H}$ NMR and EPR.

The UV-Vis results are depicted in Figure 5. When $\mathrm{Fe}^{3+}$ was added to the ligand solution ( $\mathrm{pH}$ 6.2) in metal:ligand 


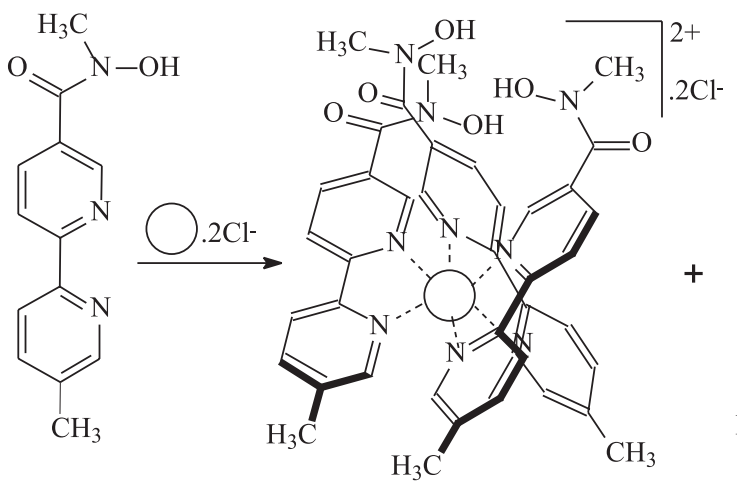

10

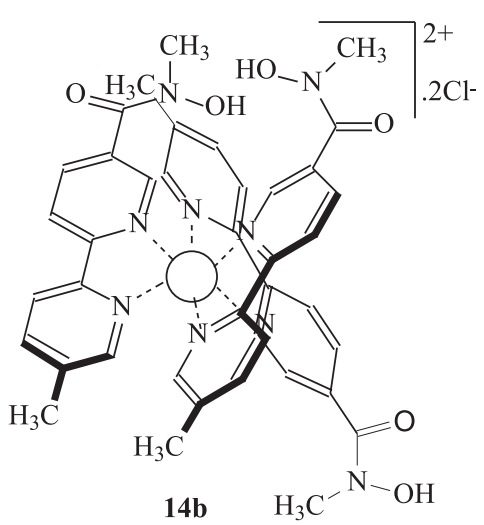

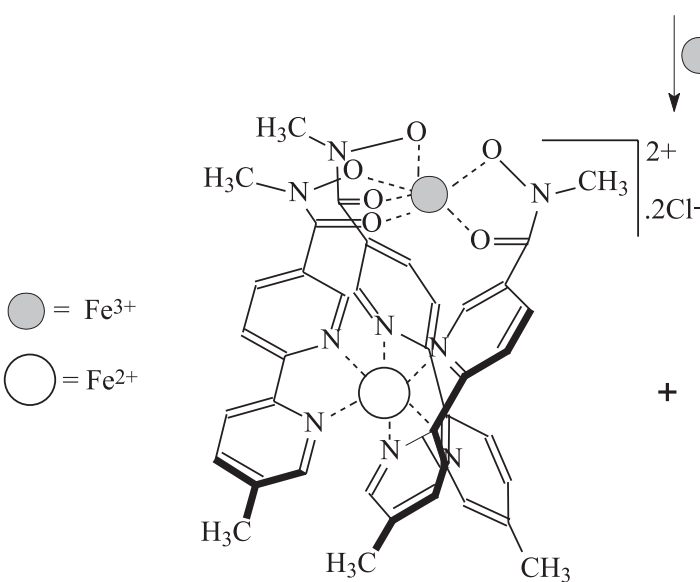

$15 \mathbf{a}$

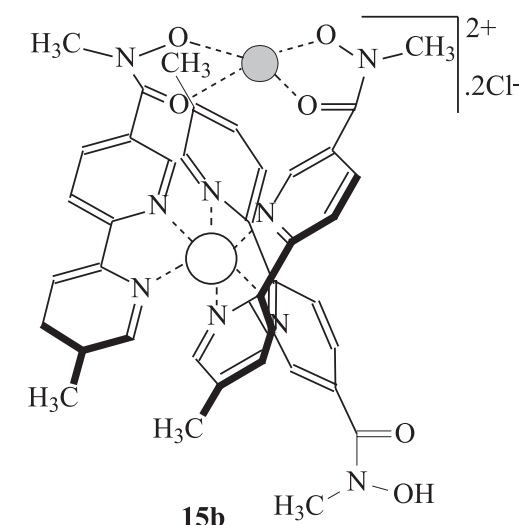

Scheme 5
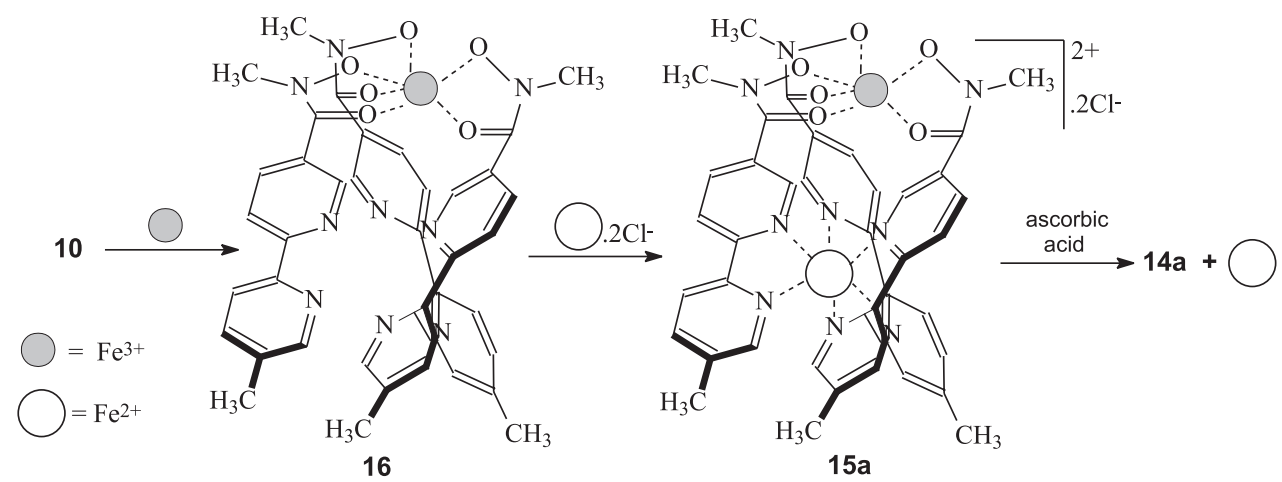

Scheme 6

1:3 ratio, the visible band at $424 \mathrm{~nm}$, characteristic of the tris(hydroxamato) $\mathrm{Fe}^{3+}$ complex, was observed. Addition of $\mathrm{Fe}^{2+}$ in the same proportion led to the formation of the (bipy) $\mathrm{Fe}^{2+}$ complex, with increase in absorbance at 530 $\mathrm{nm}$. Thereafter, reaction with ascorbic acid gave a decrease in the absorbance at $424 \mathrm{~nm}$.

The same process was also followed by ${ }^{1} \mathrm{H}$ NMR measurements (Figure 6) and revealed the transformation of the five signals from the methyl groups into only two signals, at $\delta 2.21$ and at 3.24. This is consistent with the structure of isomer $\mathbf{1 4 a}$ and corroborates the UV-Vis data and the strategy displayed in Scheme 6. The ${ }^{1} \mathrm{H}$ NMR spectrum of the same sample taken 15 days after the first experiment, did not give any indication of isomerization. 


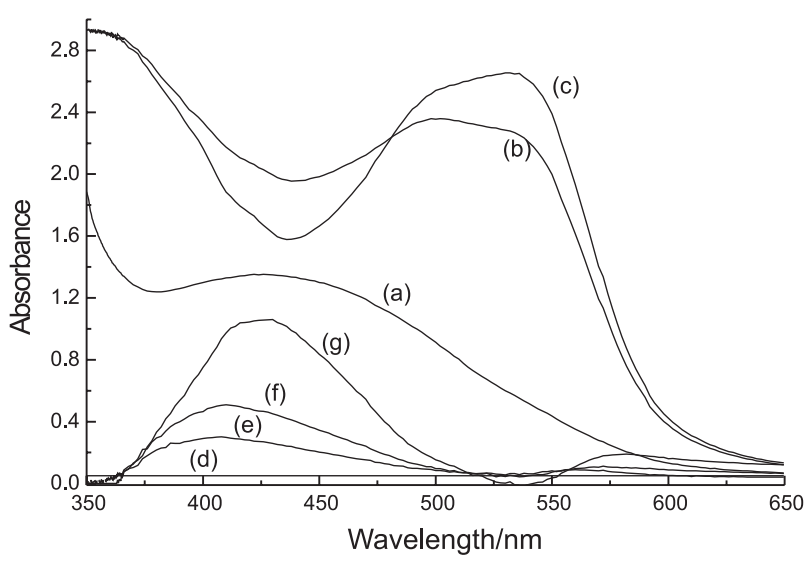

Figure 5. UV-Vis measurements for the sequential complexation experiment with ligand $\mathbf{1 0}\left(1.3 \times 10^{-3} \mathrm{~mol} \mathrm{~L}^{-1}\right.$ in methanol-buffer MES $4: 1 ; \mathrm{pH}=6.2 ; 25^{\circ} \mathrm{C}$ ). These spectra represent the following sequence of additions in the cuvette: (a) $\mathrm{FeCl}_{3}$ up to a final concentration of $4.4 \times 10^{-4} \mathrm{~mol} \mathrm{~L}^{-1}$; (b) $\mathrm{FeCl}_{2}$ (final concentration of $\left.4.4 \times 10^{-4} \mathrm{~mol} \mathrm{~L}^{-1}\right)$; (c) ascorbic acid $\left(10 \mu \mathrm{L}\right.$ of $\left.0.21 \mathrm{~mol} \mathrm{~L}^{-1}\right)$ solution; (d)-(g) titration with consecutive additions of $10 \mu \mathrm{L}$ of $\mathrm{FeCl}_{3}$ solution (final concentration $4.4 \times 10^{-4} \mathrm{~mol} \mathrm{~L}^{-1}$; baseline represented by spectrum (d), adjusted to collect these spectra).
Figure 7 depicts EPR spectra for sequential experiments with ligand 10. A sharp line was obtained for the entity involving only this ligand and $\mathrm{Fe}^{3+}$ (complex 16) in contrast to the broad lines observed for the $\mathrm{Fe}^{3+}$ complexes with ligand 4 (Figure 4). This line, with $g=4.3$, is characteristic for high spin $\mathrm{Fe}^{3+}$ in a rhombic site, corresponding to the structure of a tris(hydroxamato) $\mathrm{Fe}^{3+}$ complex. Addition of $\mathrm{Fe}^{2+}$ into a solution containing $\mathbf{1 6}$ led to the broadening of the line in the EPR spectrum, similar in shape to that observed for complexes $\mathbf{1 2}$ and $\mathbf{1 3}$. A similar EPR spectrum was obtained for the mixture with complexes 15a and 15b (Scheme 5). Since these experiments are expected to yield complexes related to $\mathbf{1 2}$ and $\mathbf{1 3}$, they provide further evidence for the latter's structures. The broadening observed may be due to a distortion of the $\mathrm{Fe}^{3+}$ sites, which would not occur in complex 16. Efforts are being made to crystallize the complexes in order to compare their solid state structures to the proposed structures in solution.

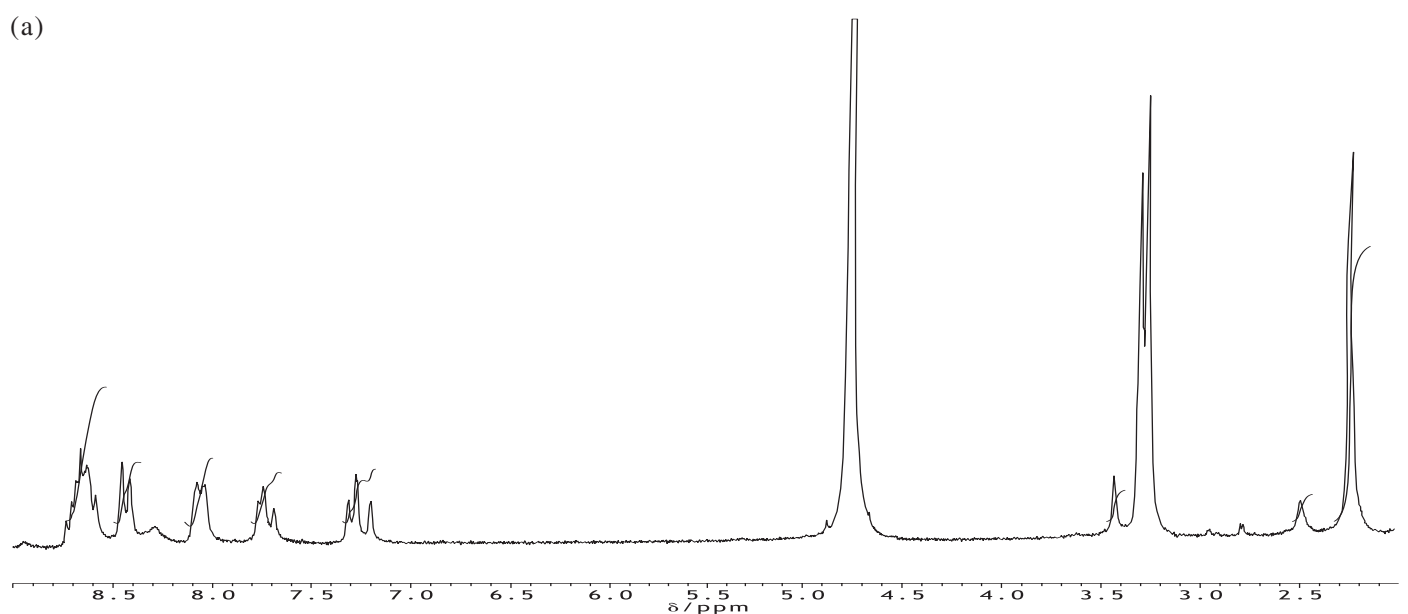

(b)

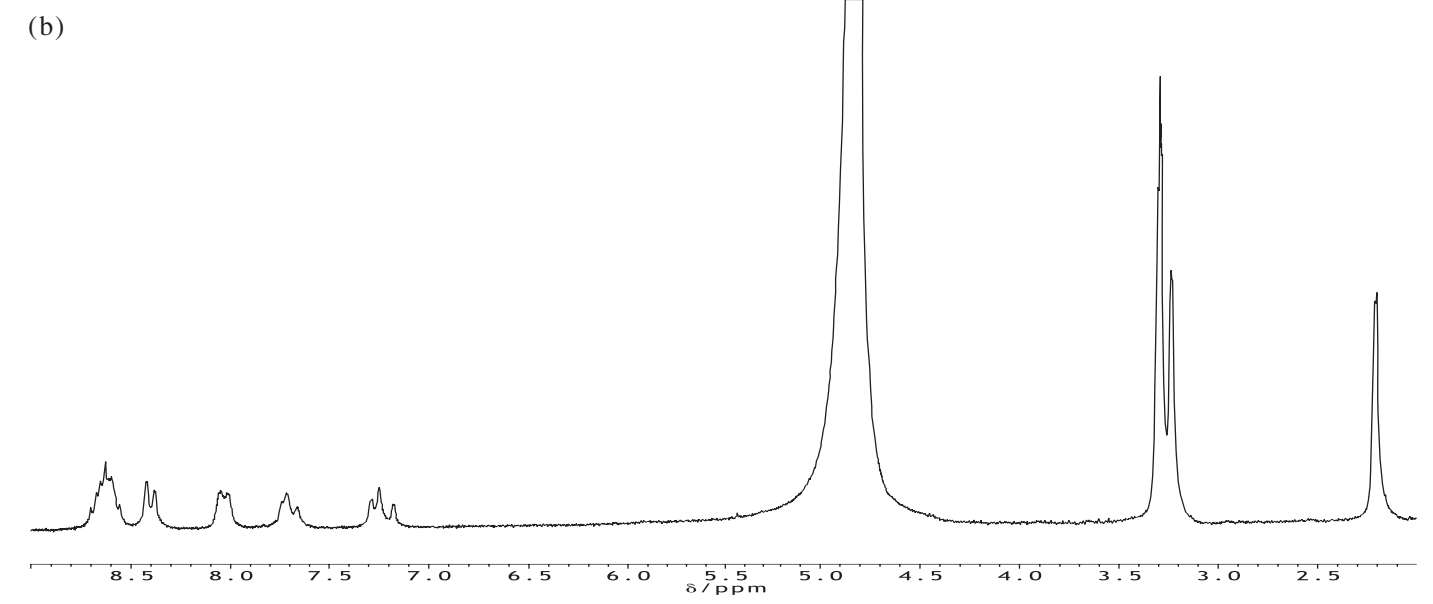

Figure 6. ${ }^{1} \mathrm{H}$ NMR spectra for (a) the mixture of complexes obtained from the reaction between ligand $\mathbf{1 0}$ and $\mathrm{Fe}^{2+}$ (see $\mathrm{Scheme} 5$ and text) and (b) the single complex obtained for the reaction between $\mathbf{1 0}$ and $\mathrm{Fe}^{3+}$ followed by the reaction with $\mathrm{Fe}^{2+}$ and reduction of $\mathrm{Fe}^{3+}$ with ascorbic acid (see Scheme 6 and text). 


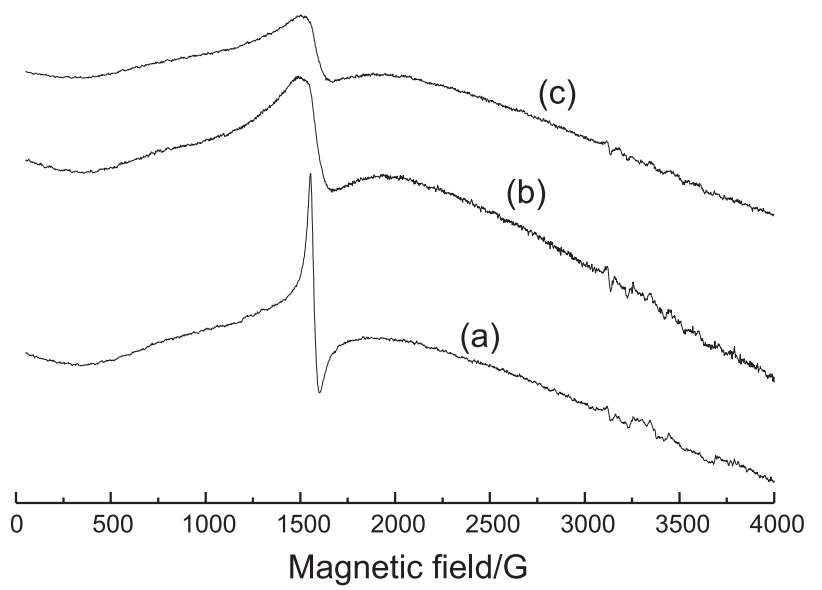

Figure 7. EPR spectra for (a) complex 16, between ligand 10 and $\mathrm{Fe}^{3+}$; (b) complexes $\mathbf{1 5} \mathbf{a}, \mathbf{b}$ formed from the experiment described in Scheme 5; and (c) complex 15a from the experiment described in Scheme 6. Spectra were taken at $77 \mathrm{~K}$ by freezing the samples in liquid nitrogen.

\section{Conclusions}

The data described above illustrate the process of selfassembly through sequential complexation in the synthesis of bimetallic and trimetallic structures from the reaction of 2,2'-bipyridine ligands bearing hydroxamic acid groups in 5,5' positions with $\mathrm{Fe}^{2+}$ and $\mathrm{Fe}^{3+}$. In addition, the studies performed in this work allow the visualization of three important aspects: the free ligand by itself is not capable of performing functions such as recognition of substrates. On complexation around the metallic ion, the ligands are organized so as to generate two secondary complexation sites capable of binding metal ions or other substrates. Furthermore, binding of the metal ion also results in a lowering of the $\mathrm{p} K_{a}$ values of the hydroxamic acids units. This interesting feature amounts to an activation of potential catalytic groups in a substrate binding pocket. It could make complexes 11 and 14a attractive as mimics of the enzymatic hydrolysis of compounds of biological interest, in mild conditions of $\mathrm{pH}$. In addition, complexes such as $\mathbf{1 1}$ and 14a display features of siderophores reminiscent of those of iron carriers in living systems. ${ }^{41}$

Finally, from a broader point of view, the stepwise, hierarchical self-assembly through sequential binding of specific substrates allows the induction and control of growth processes leading to the generation of structurally organized and functionally integrated supramolecular devices.

\section{Acknowledgments}

A.S.M. thanks CNPq and V.G.M. is grateful for financial support from Capes, CNPq, PRONEX/Química/UFSC and UNISUL.

\section{References}

1. Lehn, J.-M.; Supramolecular Chemistry, VCH: Heidelberg, 1995.

2. Lehn, J.-M.; Angew. Chem. Int. Ed. Engl. 1990, 29, 1304.

3. Balzani, V.; Juris, A.; Venturi, M.; Campagna, S.; Serroni, S.; Chem. Rev. 1996, 96, 759 .

4. Baxter, P.N.W.; Constable, E.C.; Fujita, M. In Comprehensive Supramolecular Chemistry; Atwood, J.L.; Davies, J.E.D.; Macnicol, D.D.; Vögtle, F., eds., Pergamon: Oxford, 1996, vol. 9, pp. 165-211; pp. 213-252; pp. 253-282 respectively.

5. Raymo, F.M.; Stoddart, J.F.; Chem. Rev. 1999, 99, 1643; Dietrich-Buchecker, C.; Rapenne, G.; Sauvage, J.-P.; Coord. Chem. Rev. 1999, 186, 167; Leininger, S.; Olenyuk, B.; Stang, P.J.; Chem. Rev. 2000, 100, 853; Swiegers, G. F.; Malefetse, T. J.; Chem. Rev. 2000, 100, 3483.

6. Machado, V.G.; Baxter, P.N.W.; Lehn, J.-M.; J. Braz. Chem. Soc. 2001, 12, 431.

7. Lehn, J.-M.; Rigault, A.; Siegel, J.; Harrowfield, J.; Chevrier, B.; Moras, D.; Proc. Natl. Acad. Sci. USA 1987, 27, 2565; Funeriu, D.-P.; He, Y.-B.; Bister, H.-J.; Lehn, J.-M.; Bull. Soc. Chim. Fr. 1996, 133, 673; Hasenknopf, B.; Lehn, J.-M.; Helv. Chim. Acta 1996, 79, 1643; Hasenknopf, B.; Lehn, J.-M.; Baum, G.; Fenske, D.; Proc. Natl. Acad. Sci. USA 1996, 93, 1397; Hasenknopf, B.; Lehn, J.-M.; Kneisel, B.O.; Baum, G.; Fenske, D.; Angew. Chem. Int. Ed. Engl. 1996, 35, 1838; Hasenknopf, B.; Lehn, J. -M.; Boumediene, N.; DupontGervais, A.; Van Dorsselaer, A.; Kneisel, B.; Fenske, D.; J. Am. Chem. Soc. 1997, 119, 10956; Fatin-Rouge, N.; Blanc, S.; Pfeil, A.; Rigault, A.; Albrecht-Gary, A.M.; Lehn, J.-M.; Helv. Chim. Acta 2001, 84, 1694.

8. Youinou, M.T.; Ziessel, R.; Lehn, J.-M.; Inorg. Chem. 1991, 30, 2144; Krämer, R.; Lehn, J.-M.; DeCian, A.; Fischer, J.; Angew. Chem. Int. Ed. Engl. 1993, 32, 703; Piguet, C.; Bernardinelli, G.; Hopfgartner, G.; Chem. Rev. 1997, 97, 2005; Piguet, C.; J. Inclusion Phenom. Macrocyclic Chem. 1999, 34, 361 .

9. Hanan, G.S.; Arana, C.R.; Lehn, J.-M.; Fenske, D.; Angew. Chem. Int. Ed. Engl. 1995, 34, 1122; Hanan, G.S.; Arana, C.R.; Lehn, J.-M.; Baum, G.; Fenske, D.; Chem. Eur. J. 1996, 2, 1292; Sleiman, H.; Baxter, P.N.W.; Lehn, J.-M.; Airola, K.; Rissanen, K.; Inorg. Chem. 1997, 36, 4734; Ceroni, P.; Credi, A.; Balzani, V.; Campagna, S.; Hanan, G.S.; Arana, C.R.; Lehn, J.-M.; Eur. J. Inorg. Chem. 1999, 1409.

10. Baxter, P.N.W.; Lehn, J.-M.; Fischer, J.; Youinou, M.-T.; Angew. Chem. Int. Ed. Engl. 1994, 33, 2284; Hanan, G.S.; Volkmer, D.; Schubert, U.S.; Lehn, J.-M.; Baum, G.; Fenske, D.; Angew. Chem. Int. Ed. Engl. 1997, 36, 1842; Bassani, D.M.; Lehn, J.M.; Fromm, K.; Fenske, D.; Angew. Chem. Int. Ed. Engl. 1998, 37, 2364; Rojo, J.; Lehn, J.-M.; Baum, G.; Fenske, D.; Waldmann, O.; Muller, P.; Eur. J. Inorg. Chem. 1999, 517; 
Rojo, J.; Romero-Salguero, F.J.; Lehn, J.-M; Baum, G.; Fenske, D.; Eur. J. Inorg. Chem. 1999, 1421; Garcia, A.M.; RomeroSalguero, F.J.; Bassani D.M.; Lehn, J.-M.; Baum, G.; Fenske, D.; Chem. Eur. J. 1999, 5, 1803; Breuning, E.; Ziener, U.; Lehn, J.-M.; Wegelius, E.; Rissanen, K.; Eur. J. Inorg. Chem. 2001, 1515.

11. Garcia, A.M.; Bassani, D.M.; Lehn, J.-M.; Baum, G.; Fenske, D.; Chem. Eur. J. 1999, 5, 1234; Baxter, P.N.W.; Lehn, J.-M.; Baum, G.; Fenske, D.; Chem. Eur. J. 1999, 5, 102; Baxter, P.N.W.; Lehn, J.-M.; Kneisel, B.O.; Baum, G.; Fenske, D.; Chem. Eur. J. 1999, 5, 113.

12. Smith, V.C.; Lehn, J.-M.; Chem. Commun. 1996, 2733.

13. Funeriu, D.P.; Lehn, J.-M.; Baum, G.; Fenske, D.; Chem. Eur. J. 1997, 3, 99; Funeriu, D.P.; Lehn, J.-M.; Fromm, K.M.; Fenske, D.; Chem. Eur. J. 2000, 6, 2103.

14. See for instance: Delaigue, X.; Hosseini, M.W.; Tetrahedron Lett. 1993, 34, 8111; Hajek, F.; Hosseini, M.W.; Graf, E.; De Cian, A.; Fischer, J.; Angew. Chem. Int. Ed. Engl. 1997, 36, 1760; Hosseini, M.W.; De Cian, A.; Chem. Commun. 1998, 727; Mislin, G.; Graf, E.; Hosseini, M.W.; De Cian, A.; Kyritsakas, N.; Fischer, J.; Chem. Commun. 1998, 2545; Mislin, G.; Graf, E.; Hosseini, M.W.; Bilyk, A.; Hall, A.K.; Harrowfield, J.M.; Skelton, B.W.; White, A.H.; Chem. Commun. 1999, 373.

15. Lehn, J.-M.; Angew. Chem. Int. Ed. Engl. 1988, 27, 89.

16. Uppadine, L.H.; Drew, M.G.B.; Beer, P.D.; Chem. Commun. 2001, 291

17. Telfer, S.G.; Bernardinelli, G.; Williams, A.F.; Chem. Commun. 2001, 1498.

18. Wu, B.; Yang, X.-J.; Janiak, C.; Lassahn, P. G.; Chem. Commun. 2003, 902.

19. For the synthesis of sequential ligands, see for instance: Piguet, C.; Bünzli, J.-C.G.; Bernardinelli, G.; Hopfgartner, G.; Petoud, S.; Schaad, O.; J. Am. Chem. Soc. 1996, 118, 6681; Lutz, A.; Ward, T.R.; Albrecht, M.; Tetrahedron 1996, 52, 12197; Albrecht, M.; Fröhlich, R.; J. Am. Chem. Soc. 1997, 119, 1656; Albrecht, M.; Riether, C.; Synthesis 1997, 957.

20. Zelikovich, L.; Libman, J.; Shanzer, A.; Nature 1995, 374, 790.

21. Canevet, C.; Libman, J.; Shanzer, A.; Angew. Chem. Int. Ed. Engl. 1996, 35, 2657.

22. Furniss, B.S.; Hannaford, A.J.; Smith, P.W.G.; Tatchell, A.R.; Vogel's Textbook of Practical Organic Chemistry, $5^{\text {th }}$ ed., Longman: London, 1989.

23. Coulson, D.R.; Inorg. Synth. 1972, 13, 121.

24. Ulrich, H.; Sayigh, A.A.R.; J. Chem. Soc. 1963, 1098.
25. Skoog, D.A.; West, D.M.; Fundamentals of Analytical Chemistry, $2^{\text {nd }}$ ed., Holt, Rinehart and Winston: New York, 1963, p. 437.

26. Badger, G.M.; Sasse, W.H.F.; J. Chem. Soc. 1956, 616; Sasse, W.H.F.; Whittle, C.P.; J. Chem. Soc. 1961, 1347.

27. Ebmeyer, F.; Vogtle, F.; Chem. Ber. 1989, 122, 1725.

28. Case, F.H.; J. Am. Chem. Soc. 1946, 68, 2574.

29. Bos, K.D.; Kraaijkamp, J.G.; Noltes, J.G.; Synth. Commun. 1979, 9, 497.

30. Windscheif, P.M.; Vogtle, F.; Synthesis 1994, 87.

31. Complex $\left[\mathrm{Fe}^{2+}(4)_{3}\right]\left(\mathrm{CF}_{3} \mathrm{SO}_{3}^{-}\right)_{2}$ was prepared in the same way, by mixing 4 with $\mathrm{Fe}\left(\mathrm{CF}_{3} \mathrm{SO}_{3}\right)_{2}$. This complex is very soluble in water, methanol, ethanol and acetonitrile. ${ }^{1} \mathrm{H}$ NMR (200 $\left.\mathrm{MHz}, \mathrm{CD}_{3} \mathrm{CN}\right): \delta 3.20(6 \mathrm{H}, \mathrm{s}), 7.71(2 \mathrm{H}, \mathrm{s}), 8.00(2 \mathrm{H}, \mathrm{s}), 8.37$ $(2 \mathrm{H}, \mathrm{d}, J 8.19 \mathrm{~Hz}), 8.59(2 \mathrm{H}, \mathrm{d}, J 8.19 \mathrm{~Hz})$. The signal at $\delta$ 8.00 disappears after the addition of a very small amount of water and it corresponds to the protons of hydroxamic groups.

32. Gans, P.; Sabatini, A.; Vacca, A.; J. Chem. Soc., Dalton Trans. 1985, 1195.

33. Meyer, Jr., A.S.; Ayres, G.H.; J. Am. Chem. Soc. 1957, 79, 49.

34. Job, A.; Liebigs Ann. Chem. 1928, 9, 113; Connors, K. A.; Binding Constants, Wiley Interscience: New York, 1987, ch. 2.

35. Smith, R.M.; Martell, A.E.; Critical Stability Constants, Plenum Press: New York, 1976, vol. 3.

36. Jutzi, P.; Gilge, U.; J. Organomet. Chem. 1983, 246, 163.

37. Bailey, T.R.; Tetrahedron Lett. 1986, 27, 4407.

38. Burstall, F.H.; Nyholm, R.S.; J. Chem. Soc. 1952, 3570.

39. Birus, M.; Bradic, Z.; Kujundzic, N.; Pribanic, M.; Wilkins, P.C.; Wilkins, R.G.; Inorg. Chem. 1985, 24, 3980.

40. Farkas, E.; Enyedy, E. A.; Zékány, L.; Deák, G.; J. Inorg. Biochem. 2001, 83, 107.

41. See for instance: Iron Transport in Microbes, Plants and Animals; Winkelmann, G.; Van der Helm, D.; Neilands, J.B., eds.; VCH: Weinheim, 1987; Winkelmann, G.; CRC Handbook of Microbial Iron Chelates; CRC Press: Boca Raton, 1991; Telford, J.R.; Raymond, K.N. In Comprehensive Supramolecular Chemistry Atwood, J.L.; Davies, J.E.D.; Macnicol, D.D.; Vögtle, F., eds., Pergamon: Oxford, 1996, vol. 1, p 245; Albrecht-Gary, A.M.; Libman, J.; Shanzer, A.; Pure Appl. Chem. 1996, 68, 1243; Meyer, M.; Telford, J.R.; Cohen, S.M.; White, D.J.; Xu, J.; Raymond, K.N.; J. Am. Chem. Soc. 1997, 119, 10093.

Received: March 17, 2003 Published on the web: August 15, 2003 